\title{
Integrated Management of Non-Native Plants in Natural Areas of Florida ${ }^{1}$
}

\author{
Stephen F. Enloe, Ken Langeland, Jason Ferrell, Brent Sellers, and Greg MacDonald ${ }^{2}$
}

\section{Introduction}

Florida's natural areas encompass an incredible diversity of native plants and animals and provide a wide array of ecosystem services that benefit Florida greatly. Within the state, there are almost ten million acres of local, state, and federal public lands currently managed as natural areas for conservation. While natural areas are conservation lands that have been set aside for the purpose of preserving (or restoring) native plant and animal communities, they do require active management. One of the greatest management issues in natural areas is invasive plants. Invasive plants are species that are not native to the ecosystem under consideration and whose introduction causes or is likely to cause economic or environmental harm or harm to human health. Invasive plants represent a subset of non-native plants that have been introduced into Florida. Of the approximately 4,798 plant species growing without cultivation in Florida, 31\% are non-native (Wunderlin et al. 2018). Many of these non-native plants were originally introduced as garden ornamentals, agricultural crops, forages, or soil stabilizers. Others were accidentally introduced as contaminants of seed or as hitchhikers on animals or materials.
Regardless of how they arrived, these 1,400+ non-native plants grew so well in Florida that they established and reproduced on their own and spread into natural areas. Out of these 1,400+ species, approximately $165(11 \%)$ are considered invasive and may disrupt ecosystem services vital to the integrity of Florida natural areas (FLEPPC 2017). Among these, approximately 100 species require aggressive management.

Management of invasive vegetation in natural areas requires control methods that will minimize damage to non-target vegetation and soil. This need for caution often necessitates more time and effort than weed management in agricultural, industrial, or right-of-way settings does. Certain types of vegetation, such as woody or sprawling vegetation, may require removal of standing plant material even after they have been killed if the presence of standing material increases fire hazard, reduces aesthetic appeal, or has the potential to cause harm as it decays and falls. Control methods include cultural, preventative, manual, and mechanical removal, biological control, physical controls, and herbicides. Generally, these tools are utilized as part of a comprehensive management plan that considers

1. This document is SP 242, one of a series of the Agronomy Department, UF/IFAS Extension. Original publication date January 1997. Revised July 2018. The original document was prepared in cooperation with the Metropolitan Dade County Park and Recreation Department, Natural Areas Management, and the Florida Exotic Pest Plant Council. Visit the EDIS website at http://edis.ifas.ufl.edu.

2. Stephen F. Enloe, associate professor; Ken Langeland, professor emeritus; Jason Ferrell, professor, Agronomy Department, UF/IFAS Center for Aquatic and Invasive Plants; Brent Sellers, professor, Agronomy Department, UF/IFAS Range Cattle Research and Education Center; and Greg MacDonald, professor, Agronomy Department, UF/IFAS Center for Aquatic and Invasive Plants; UF/IFAS Extension, Gainesville, FL 32611.

The use of trade names in this publication is solely for the purpose of providing specific information. UF/IFAS does not guarantee or warranty the products named, and references to them in this publication do not signify our approval to the exclusion of other products of suitable composition. All chemicals should be used in accordance with directions on the manufacturer's label. Use pesticides safely. Read and follow directions on the manufacturer's label.

The Institute of Food and Agricultural Sciences (IFAS) is an Equal Opportunity Institution authorized to provide research, educational information and other services only to individuals and institutions that function with non-discrimination with respect to race, creed, color, religion, age, disability, sex, sexual orientation, marital status, national origin, political opinions or affiliations. For more information on obtaining other UF/IFAS Extension publications, contact your county's UF/IFAS Extension office. 
a wide range of issues to control invasive plants and protect the native plants of a given natural area. These tools are not silver bullets and cannot be expected to solve invasive plant problems with a one-time shot. Eradication, which is the complete elimination of all living propagules of a species, is extremely difficult and often infeasible for well-established invasive plants. Without a clear management plan and long-term commitment, most single invasive plant control efforts result in short-lived success.

This publication provides land managers in Florida with current methods used to manage non-native plants. It does not address identification of plant species. For information on identification and recognition of many invasive plant species, consult Identification and Biology of Nonnative Plants in Florida's Natural Areas, $2^{\text {nd }}$ Ed. by K. A. Langeland, H. M. Cherry, C. M. McCormick, and K. A. Craddock Burks (2008), which is available from the UF/IFAS Extension Bookstore (http://ifasbooks.ifas.ufl.edu).

\section{Regulatory Agencies, Permits, Plant Lists, and the UF/IFAS Assessment}

There has been much confusion over the legal ramifications of listing certain plants as invasive. The best example of this is the Florida Exotic Pest Plant Council (FLEPPC) Invasive Plant List. FLEPPC is a nonprofit professional organization founded in 1984 to increase public awareness of the significant threat that non-native invasive plant species pose to native species, communities, and ecosystems, and to develop integrated management and control strategies to halt the spread of exotic species in natural areas. FLEPPC maintains a list of plant species considered by a committee of botanists, ecologists, and land managers to be invasive in Florida. This list is available on the FLEPPC website (http:// www.fleppc.org). The purpose of the FLEPPC list is to alert land managers to plant species that have demonstrated invasiveness in Florida. However, the list does not have statutory authority.

Plants that are legally regulated by statute are listed on the Florida Noxious Weed List, which can be found on the Florida Department of Agriculture and Consumer Services website (http://www.freshfromflorida.com/ Divisions-Offices/Plant-Industry/Bureaus-and-Services/ Bureau-of-Entomology-Nematology-Plant-Pathology/ Botany/Noxious-Weeds). There may also be local, county, or city ordinances regarding certain plants, but they are beyond the scope of this publication.
Plant species included in this publication are not limited to either of these lists. They are included because they have warranted control measures in at least one natural area in the state and should be viewed as potentially invasive in other natural areas. Some of the plants are still used in landscaping and sold in the nursery industry.

Mention of species in this publication does not necessarily mean UF/IFAS recommends limitation of their use. The UF/IFAS Assessment of Non-Native Plants in Florida's Natural Areas is used by UF/IFAS to evaluate the invasiveness of non-native plants in Florida relative to UF/IFAS recommendations. The results of this assessment can be viewed on the UF/IFAS Assessment website: https:// assessment.ifas.ufl.edu/. The UF/IFAS assessment is not regulatory. However, all UF/IFAS employees are required to follow the results of the assessment when making plant species recommendations.

Finally, the removal of vegetation in certain areas such as public waters and wetlands is regulated by state and local agencies. A permit may be required. For questions regarding permits to control vegetation in public waters, please visit the Florida Fish and Wildlife Conservation Commission Invasive Plant Management Section website: http://www.myfwc.com/wildlifehabitats/invasive-plants/. The FWC Invasive Plant Management Section is the lead agency in Florida responsible for coordinating and funding two statewide programs that control invasive upland and aquatic plants on public conservation lands and waterways throughout the state. The agency also ensures that beneficial native aquatic plants in Florida's ponds, lakes, and rivers are protected through permitting programs and funding of research to find more cost-effective management techniques.

For regulatory questions regarding vegetation control in wetlands, contact the Water Management District (WMD) in which you are located. These can be found at the Florida Department of Environmental Protection website: https://floridadep.gov/water-policy/water-policy/content/ water-management-districts.

\section{Acknowledgements}

The following individuals have provided information for this or previous editions of Integrated Management of Nonnative Plants in Natural Areas of Florida: Mike Bodle, Jim Burney, Mathew Cole, Rodell Collins, Jim Cuda, Scott Ditmarsen, Jim Duquesnel, Roger Hammer, Dallas Hazelton, Jeff Hutchinson, Greg Jubinsky, Chris Key, Bill Kline, Mike Link, Mark Ludlow, Joe Maguire, Chris Marble, 
Michael Meisenburg, Vince Miller, Patrick Minogue, Shawn Moore, Romeo Morua, Brian Nelson, Jose Prieto, Jerry Renny, Adolfo Santiago, and Elroy Timmer.

\section{Control Methods}

\section{Education and Prevention}

Public education can significantly reduce the introduction and spread of invasive plants. Many in the general public are still unaware of problems caused by invasive plants and unable to recognize invasive species. There are numerous educational resources available online. A great starting point is the UF/IFAS Center for Aquatic and Invasive Plants (http://plants.ifas.ufl.edu/). Its webpage provides information on the identification, history, biology, ecology, and control of hundreds of species. Additionally, the Center hosts the Florida Invasive Plant Education Initiative and Curriculum, which is focused on providing material for educators. Other educational sites tailored specifically to the general public include PlayCleanGo.org and invasive. org.

\section{Biological Control}

Classical biological control is the introduction of reproducing populations of foreign insects or diseases that are host-specific and provide suppression of the target weed. Biological control efforts for weeds have a long history in Florida, but they have primarily focused on aquatic weeds, including alligatorweed, waterhyacinth, water lettuce, salvinia, and hydrilla. These efforts have yielded mixed outcomes, with the most effective results on alligatorweed and the least effective on hydrilla and water lettuce. In more recent years, efforts to develop biological controls for natural area weeds have focused on air potato (Dioscorea bulbifera), melaleuca (Melaleuca quinquenervia), tropical soda apple (Solanum viarum), Brazilian pepper (Schinus terebinthifolia), and Old World climbing fern (Lygodium microphyllum) (Table 1). Air potato biocontrol is quickly becoming a success story in many areas of Florida. The air potato leaf beetle has provided a high level of suppression, greatly reducing the number of aerial bulbils produced in many natural areas. Additionally, the suite of biocontrols released for melaleuca has been very effective in suppressing melaleuca growth and reproduction, especially after initial control efforts with herbicides and prescribed fire have been implemented. Tropical soda apple has declined in many areas following the release of Gratiana boliviana in 2003. While these are promising, the majority of invasive plants in natural areas in Florida still do not have biocontrol options. Classical biological control is a slow process requiring intensive vetting of prospective candidates to ensure both effectiveness and host specificity. In many cases, biological control may not be possible due to a lack of host-specific agents. However, research on Brazilian peppertree and Old World climbing fern is ongoing, and new efforts are underway on cogongrass, earleaf acacia, and downy rose myrtle. Biological control programs are typically implemented by state and federal agencies, and the potential role of individual resource managers and the public will depend on the particular action being implemented. Current information on the status of these and other biological control programs can be found at http://edis.ifas.ufl.edu/ topic_biological_control_of_weeds.

In addition to insects and pathogens, the use of herbivores such as cattle, sheep, goats, and sterile grass carp is possible for suppression or control of certain invasive plants. For example, kudzu has been reported to be effectively controlled with all classes of livestock (Loewenstein and Enloe 2014). Goats are very effective for controlling Chinese privet and many other invasive shrubs. However, use of herbivores for weed control on public lands in Florida is limited primarily due to higher costs of intensive grazing management. Grazing animals are often used on private lands across Florida to manage invasive plants.

\section{Manual Removal}

Manual removal is a labor-intensive but often major component of effective invasive plant control. Seedlings and small saplings can sometimes be pulled from the ground, but even small seedlings of some plants have tenacious roots that will prevent extraction or cause them to break at the root collar. Plants that break off at the ground will often resprout, and small root fragments left in the ground may produce new plants. Therefore, repeated hand pulling or follow-up with herbicide applications is often necessary. Hand pulling is easiest in sandy soils for immature shallowrooted plants and most difficult in clay and rocky soils for well-established plants with extensive root systems.

Manual removal may require a wide variety of implements, including shovels, saws, pick axes, Pulaski tools, and woody plant extraction tools such as the Uprooter ${ }^{\curvearrowleft}$ or the Extractigator ${ }^{\circledast}$.

Regardless of the method, one major consideration in manual removal is disposal of the biomass after removal. Leaving it on the ground is often risky because stems of many species left on moist soils will root and establish new plants. Melaleuca, Tradescantia, Ligustrum, Phyllostachys, Selenicereus (Hylocereus), Kalanchoe, and Epipremnum are species that have spread in this manner. If removed biomass 
cannot be destroyed by methods such as burning, it should be piled in a delineated area that can be monitored where new plants can be controlled as they appear.

A second major consideration in manual removal is the extensive soil disturbance that often occurs in the process. Plant roots are often well-anchored in the soil; pulling plants may disrupt soil structure. This type of soil disturbance may result in further invasion by other non-native plant species and require additional follow-up control measures.

\section{Mechanical Removal}

Mechanical removal involves the use of bulldozers or specialized logging equipment (skid steer mulchers) to remove woody plants. Intense follow-up with other control methods is essential after the use of heavy equipment because disturbance of the soil creates favorable conditions for regrowth from seeds and root fragments as well as recolonization by invasive non-native plants. Plans for management and replanting of sites with native vegetation following mechanical removal should be carefully developed prior to implementation. Mechanical removal may not be appropriate in many natural areas because of the disturbance to soils and nontarget vegetation.

\section{Cultural Practices}

Prescribed burning and water level manipulation are cultural practices that are used in management of pastures, rangeland, and commercial forests. In certain situations, they may be appropriate for vegetation management in natural areas. One important consideration is the degree of degradation of the area in question. Cultural practices may affect all parts of the habitat, including native species. If the habitat is so badly degraded that the need to reduce invasive plants strongly outweighs consideration of remaining native species, more aggressive control strategies can be considered. In less degraded areas, more careful use of integrated methods may be more appropriate.

The land use history of an area is critical in understanding the effects of fire and flooding on the resulting plant species composition. Past practices affect soil structure, organic matter content, species seed bank (both native and invasive non-native species), and species composition. While past farming and timber management practices may influence the outcome of cultural management, very little is known about the effects of specific historical practices. Similar management practices conducted in areas with different histories may achieve very different results. Even less is known about the effects of invasive plants in these communities, and the subsequent management effects of fire on the altered communities.

Understanding the reproductive biology of the target and nontarget plant species is critical to effective use of any control methods, especially fire management, that require significant preparation time. Important opportunities exist if management tools can be applied to habitats where non-native invasive species flower or set seed at different times than the native species.

\section{PRESCRIBED BURNING}

Fire is a normal part of most of Florida's ecosystems. Native species have developed varying degrees of fire tolerance. Throughout much of Florida, suppression of fire during this century has altered historical plant communities, such as flatwood and oak scrub communities, enhancing fireintolerant species and reducing the coverage of species that possess fire adaptations. Within these communities, the fire-tolerant woody species have lingered in smaller numbers, and less fire-tolerant species have replaced ephemeral forbs. Fire ecologists are developing an understanding of the amount, frequency, timing, and intensity of fire that would best enhance the historically fire-tolerant plant species, but little is known about how such a fire management regime could best be used to suppress invasive species.

In general, fire can be used to suppress plant growth and kill certain plants that are not fire-tolerant. Woody species are often reduced, but effects are less noticeable on herbaceous species. Some information has been published on responses of individual Florida plant species, but very little is known about the vast majority of native plant species. Even less is known about invasive exotic species. Tolerance to fire can sometimes be predicted in species that have thick bark or seeds in the soil or in the canopy; are adapted to fire (either tolerant of high temperature or requiring fire for seed release or germination); and have seeds that are disbursed over a wide area.

Added biomass by invasive plants can result in hotter fires and greatly increase the risk of fires spreading to inhabited areas. In these situations, use of fire to reduce standing biomass of invasive species may protect the remaining plant populations more effectively than inaction, but impacts to nontarget native species will occur. Under these conditions, the expense of reducing standing biomass of invasive plant species might be justified by the savings on subsequent fire suppression. Additionally, in certain cases, invasion of tree stands by exotic vines and other climbing plants has greatly 
increased the risk of canopy (crown) fires and the resulting death of mature trees.

Effects of a single burn are hard to predict. Under certain conditions, a single fire effect can persist for several growing seasons. The intensity of the fire, the timing (fire during the growing season can be more destructive than during dormant seasons), and the plant species involved determine the duration of the effect. Smoke is now recognized as a triggering mechanism for germination in fire-dependent and some non-fire-dependent species, so plant species composition following a burn is due in part to the type of fire and the distribution of its smoke. A single burn may or may not start a replacement sequence (succession) with its own effects on species composition.

Fire's potential to play a logical role in suppression or elimination of invasive exotic plant species depends on many factors. In addition to the aforementioned factors, the resource manager must consider potential fire effects on soil loss and water quality, historical and economic impacts to buildings, possible harm to human life, and the potential for a fire's escape to nontarget areas.

Fire has been successfully used to manage plant species in grasslands, to maintain open savannahs (scattered trees in habitats dominated by herbaceous species), and to promote seral (fire-induced or fire-tolerant) stages of forest succession. However, very little is known about the use of fire to enhance native species while reducing invasive exotic plant species. As a final word of caution regarding the use of fire, overly frequent burning has been shown to reduce plant diversity under many conditions. It is also possible that increased fire frequency could provide opportunities for invasive plants to enter new areas.

\section{WATER LEVEL MANIPULATION AND HYDROLOGIC RESTORATION}

Some success has been achieved by regulating water levels to reduce invasive plant species in aquatic and wetland habitats. Dewatering aquatic sites reduces standing biomass. However, little else is usually achieved unless the site is rendered less susceptible to repeated invasion when rewatered. Planting native species may reduce the susceptibility of aquatic and wetland sites in some cases.

In most situations, water level manipulation in reservoirs and hydrologic restoration (recreation of natural hydrologic conditions) have not provided the level of invasive plant control that was once thought achievable. Ponds and reservoirs can be constructed with steep sides to reduce a habitat's susceptibility to invasion, and levels that promote invasive species can be avoided, but rarely are these management options adaptable to natural areas.

Carefully timed water level increases after mechanical removal, prescribed fire, or herbicide treatment of invasive species has been one of the most effective methods of water level manipulation. This integrated approach can provide effective control of subsequent germination and, with some species, resprouting. This is often most easily accomplished during the transition from the dry to the wet season in early summer when water levels typically begin to increase. Specific methods applicable to natural areas have not been clearly described.

\section{REESTABLISHMENT OF NATIVE PLANT SPECIES}

Planting native species can be an effective but expensive way to reduce the likelihood of exotic species reinvasion following removal of non-native species. Commercial plant nurseries currently offer seeds and plants of several wetland and upland species. Because some species cover a wide range of habitats and latitudes, care should be taken to obtain plant material suitable to the habitat under consideration. Seed collected from plants growing in northern latitudes may do poorly in Florida. Introduction of seeds, plant parts, or whole plants should include thorough screening for any unwanted plant or animal pests.

It often takes several years for plantings to become thoroughly established. Extra water, nutrients, and protection from fire and pests may be necessary for a while. During this establishment phase, past management practices may also have to be altered to avoid injury to the plantings. For example, if periodic burning or flooding is part of the current management practice, it may be necessary to reduce the intensity or duration until the plantings are able to exhibit their typical resistance to injury. Unfortunately, little is known about requirements for successful establishment of many native species, and less is known about their tolerances to cultural invasive plant management techniques. Even when tolerances are better understood, responses may be affected by historical site effects, traits of particular genetic strains, site-specific nutrition, soil mycorrhizae, light conditions, and interactions of soil type, hydroperiod, and microclimate. 


\section{Chemical Control (Herbicides) TRAINING AND CERTIFICATION}

Anyone who applies herbicides in natural areas should have basic training in herbicide application. This publication only addresses topics pertinent to herbicide use in natural areas. Therefore, the reader is expected to have prior knowledge of basic herbicide application techniques.

A pesticide or its use is classified as restricted if it could cause harm to humans or to the environment unless applied by certified applicators who have the knowledge to use pesticides safely and effectively. The basic knowledge of herbicide technology and application techniques needed for safe handling and effective use of any herbicides can be obtained through restricted use pesticide certification training. This training is available through UF/IFAS. Certified applicators can be licensed as either public applicators or commercial applicators. Persons must successfully complete a general standards core examination and a category examination before they can apply to the Florida Department of Agriculture and Consumer Services (FDACS) for a license. Categories applicable to target species in the publication include the Natural Areas category and/or Aquatics category. Additional information about pesticide applicator licensing can be found on http://edis.ifas.ufl.edu and http://www.freshfromflorida.com/Divisions-Offices/ Agricultural-Environmental-Services.

\section{HERBICIDE ACTIVE INGREDIENTS AND FORMULATIONS}

An herbicide formulation, or product, consists of the herbicide active ingredient dissolved in a solvent (e.g., oil, water, or alcohol) or adsorbed to a solid such as clay. Formulations often include an adjuvant that facilitates spreading, sticking, and wetting of the spray solution. Special ingredients may also improve the safety, handling, measuring, and application of the herbicide. Products mentioned in this publication contain the active ingredients 2,4-D, aminocyclopyrachlor, aminopyralid, fluazifop, glyphosate, hexazinone, imazamox, imazapyr, metsulfuron, sethoxydim, and triclopyr (Table 2).

The active ingredients 2,4-D amine, aminopyralid, aminocyclopyrachlor, triclopyr amine, triclopyr acid, triclopyr choline, imazamox, imazapyr, and hexazinone are formulated as water-soluble liquids (L). They are generally not compatible with oil-based diluents and are instead diluted in water for foliar applications. For cut-stump applications, they are diluted in water or applied in their concentrated form. These ingredients are not normally used for basal bark applications. Triclopyr acid is the exception, as it can also be mixed with oil and applied as a basal bark treatment.

Triclopyr ester, imazapyr, fluazifop, and sethoxydim are formulated as emulsifiable concentrates (EC). Emulsifiable concentrates are compatible with oil-based diluents and also contain emulsifiers that allow the formulation to mix with water. Agitation is used to mix the ECs in water. They may be diluted in water for foliar applications or mixed with oil-based diluents for basal bark applications.

\section{WHERE HERBICIDES CAN BE USED}

No pesticide may be sold in the United States until the United States Environmental Protection Agency (EPA) has reviewed the manufacturer's application for registration and determined that use of the product will not present unreasonable risk to humans or the environment. Pesticide users are required by law to comply with all instructions and directions for use on pesticide labels.

The EPA approves use of pesticides on specific sites, i.e., for use on individual crops, terrestrial non-crop sites, or aquatic areas. Only those herbicides registered by the EPA specifically for use in aquatic sites can be applied to plants growing in lakes, rivers, canals, etc. For terrestrial uses, the EPA requires herbicide labels to have the following statement: "Do not apply directly to water, to areas where surface water is present, or to intertidal areas below the mean high mark." (Dow AgroSciences 2008). Several active ingredients in this publication have separate products that are registered for direct application to water for control of aquatic weeds (Table 2). Other products mentioned can be used in non-cropland areas and certain low-lying areas, including wetlands, but cannot be applied directly to water (Table 2).

\section{ABSORPTION CHARACTERISTICS}

Herbicides recommended in this publication for invasive plant control are systemic. They move within the plant to the site where they are active after absorption by foliage, roots, or bark. The following herbicides can be absorbed by plant leaves and are effective for foliar applications: 2,4-D, aminocyclopyrachlor, aminopyralid, glyphosate, imazamox, imazapyr, metsulfuron, and triclopyr. Addition of an appropriate surfactant, as recommended on the herbicide label, is essential. Triclopyr, 2,4-D, and glyphosate are adsorbed by soils or broken down quickly in soil and are not absorbed effectively by plant roots. However, aminopyralid, aminocyclopyrachlor, imazamox, imazapyr, hexazinone, and metsulfuron are readily absorbed by plant roots (Table 3 ). 
Only oil-soluble herbicide formulations (i.e., emulsifiable concentrates) are absorbed readily through tree bark.

\section{BEHAVIOR IN SOILS}

Herbicides used for invasive plant control vary in their persistence and sorption to soils (Table 3). The most important factor is the ability of various soil types to chemically bind herbicides. Soil-applied herbicides, such as hexazinone, have label recommendations that vary the application rate for different types of soils. In general, soils with more organic matter and/or clay have greater capacities for binding herbicides than coarse, sandy soils and require higher application rates. Because woody plants are a problem on a range of Florida soils, including highly organic muck, sand, and very thin soil layers over limestone, a broad range of herbicide behavior in different soils can be expected. Generally, soil activity can be a double-edged sword: it can improve herbicide activity (i.e., imazapyr for cogongrass control) but potentially result in nontarget damage (i.e., imazapyr damage on oaks). Applicators should use herbicides with soil residual activity carefully to prevent nontarget issues.

\section{SELECTIVITY}

Herbicide selectivity is highly desirable in natural areas as protection of native plant species is critical. The ability to selectively control target vegetation with herbicides without harming nontarget plants is related to the sensitivities of target and nontarget plants, absorption and chemical characteristics of the herbicides, and placement.

Herbicides vary in their potential to damage nontarget vegetation. Unwanted results can be prevented or minimized by making the best choice of herbicides in conjunction with careful application. Fluazifop and sethoxydim, which kill many grasses, can be used to selectively manage invasive grass species among nontarget broadleaf plant species. Formulations that contain the active ingredients 2,4-D, metsulfuron, and triclopyr can often be used selectively because many broadleaf species are more sensitive to them than perennial grasses are. Because 2,4-D, triclopyr, and glyphosate have little root activity and break down quickly (Table 2), they have little potential for causing nontarget damage due to root absorption when carefully applied to target vegetation. However, caution must be used with root-active herbicides (i.e., aminocyclopyrachlor, aminopyralid, hexazinone, and imazapyr) to minimize damage to nontarget vegetation by root absorption. In shallow, porous soils, extra care should be taken to avoid root absorption of all herbicides by nontarget plants.
Care must also be taken to avoid unwanted drift of herbicide spray to nontarget plants when applications are made. Particulate drift can be minimized by avoiding windy conditions while spraying and by using low pressures and large nozzle orifices. Volatile compounds such as ester formulations may cause nontarget damage due to vapor drift when applied on hot days. This damage, which may be observed as wilting or curling leaves, has been minimal and has not caused permanent harm to most woody nontarget plants.

\section{WILDLIFE TOXICITY}

Invasive plant management is often conducted in natural areas to maintain or restore wildlife habitat. Therefore, it is essential that the herbicides themselves are not toxic to wildlife. Assessment of risk to wildlife is conducted as part of the registration procedure for herbicides and is determined as the product of hazard and exposure. Hazard is measured as the toxicity of the herbicide to test animals, and exposure depends on the use and persistence of the compound. Herbicides recommended in this publication have shown very low toxicity to wildlife with the exception of the relatively low $\mathrm{LC}_{50}$ of triclopyr ester $(0.87 \mathrm{ppm})$ and fluazifop $(0.53 \mathrm{ppm})$ for fish. Neither of these can be applied directly to water (Table 3 ). Ester formulations are toxic to fish because they irritate gill surfaces. However, because triclopyr ester and fluazifop are not applied directly to water, are absorbed by soil particles, and have low persistence, exposure is low, which results in low risk when properly used.

\section{Herbicide Application Methods Foliar Applications}

Herbicide in foliar applications is diluted in water and applied to the leaves with aerial or ground equipment. Dilution is usually about 20 parts water to 1 part herbicide concentrate (5\%) for aerial applications, and 30 to 400 parts water to 1 part herbicide concentrate (3.0-0.25\%) when making ground applications for woody plant control. Adjuvants, such as surfactants, drift control agents, or other spray modifiers, are often added to the spray mix as specified on the herbicide label. Ground equipment ranges from handheld spray bottles for applications to small individual plants to large high-pressure vehicle- or boat-mounted sprayers for larger areas. Foliar applications can either be directed, to minimize damage to nontarget vegetation, or broadcast. Broadcast applications are used where damage to nontarget vegetation is not a concern or where a selective herbicide is involved. 
For directed spray or selective applications, backpack sprayers such as the Solo Model 475 with diaphragm pump or Hudson SP1 are commonly used. A spray tip such as a TP 2503 or TP 2504 produces large spray droplets to reduce spray drift. The 2503 spray tips may be installed in the spray wand that comes with the backpack sprayer, or a Model 30 GunJet with the 2503 or 2504 spray tip may be attached to any backpack spray unit. If an adjustable tip is used, a TeeJet 5500 or equivalent is recommended. All backpack sprayers and spray guns should have chemical-resistant seals for the herbicides being used.

Power-driven ground equipment is commonly used to spray large and/or tall plants or large areas. Properly adjusted equipment should deliver a uniform spray with nozzle pressures of about 30 to $80 \mathrm{psi}$ and should generate large spray droplets to reduce potential for spray drift. Higher spray pressures produce many small spray particles that may drift onto sensitive desirable plants adjacent to the treated area. Application is performed by directing the spray onto the target foliage. Be sure to spray the growing tips and terminal leader. Techniques must be employed to prevent the spray from coming into contact with foliage of desirable plants.

Commonly used power equipment consists of portable, power-driven spray units mounted on a truck or all-terrain vehicle. A wide variety of pumps, tanks, and accessories is used. The most common and maintenance-free pump is a diaphragm pump driven by a gasoline engine, or a self-contained, 12-volt pump unit. Routinely used spray guns are Spraying Systems Model 2 and 2A GunJets. These are adjustable spray guns that produce patterns ranging from a solid stream to a wide cone spray. These spray guns may produce small spray particles at the cone spray setting, resulting in spray drift. A Model 30 GunJet with a TeeJet $5500-\mathrm{X} 10$ adjustable tip is very effective for power sprayers. Dual spray GunJets that accommodate two flat spray tips with different volumes and patterns are available. The spray gun can immediately be switched from one spray tip to the other by rotating the spray head. The most commonly used spray tips for the spray gun are TP 0512, TP 4010, or TP 4020. These tips produce few fine-spray particles, so spray drift potential is reduced.

\section{Basal Bark Applications}

In basal bark applications, herbicide is applied, commonly with a backpack sprayer, directly to the bark around the circumference of each stem or tree up to 12-18 inches above the ground. The herbicide must be in an oil-soluble formulation (EC). If it is not in a ready-to-use form, it may be mixed with a specially formulated penetrating oil.
There are also two modified methods using the basal bark approach. The first is a basal stem treatment. This is similar to basal bark, except it is used for non-woody to semiwoody species such as bowstring hemp, or large vines such as golden pothos. The lower section of stems is carefully treated in this method. The second is an apical bud treatment. This is often done for invasive palm trees and certain herbaceous plants such as oyster plant. In this treatment, the terminal growing point of each stem is sprayed until wet with the typical triclopyr ester herbicide at $10-20 \%$ in an oil carrier. For palms, this is useful for solitary trunked palms but much more difficult for multi-stemmed clusters. Care should be taken to avoid the sharp, spiny growth of certain palms, most notably the Senegal date palm.

For all basal bark or modified basal bark approaches, the spray tip should be a narrow angle $\left(15-25^{\circ}\right)$, flat fan-tip nozzle such as a TP 1502, TP 1503, or TP 2502/TP 2503, a solid cone nozzle, or an adjustable cone jet such as a TeeJet $5500-\mathrm{X} 4$ or $5500-\mathrm{X} 5$ or equivalent. Any of these tips can be installed in the spray wand that comes with the spray unit. A good alternative is a brass tip shutoff wand, such as a Spraying Systems Model 31 with brass extension and tip shutoff or a Spraying Systems Model 30 GunJet. A TP-0001/ TP-0002 tip or DE-1/DE-2 disc should be used with the Model 30 GunJet. The GunJet can be attached to most backpack spray units that produce pressures between 20 and 50 psi. All backpack sprayers and spray guns should have chemical-resistant seals for the herbicides and carriers in use.

\section{Hack-and-Squirt, Frill, and Girdle Applications}

These techniques involve making angled downward cuts through the bark and cambium into the shallow sapwood with a machete or hatchet around the circumference of the tree. A concentrated herbicide solution is then applied into the cuts, often with a squirt bottle. Cuts should be made in a continuous or overlapping pattern or in an evenly spaced pattern as directed by the herbicide label. Frill cuts are used for species with pliable bark that can almost be peeled down to make a larger cup for the herbicide application. Girdling is an extreme hack approach where a band of bark, often 4 to 6 inches wide, is removed. Girdling is used for control of melaleuca and some other large, difficult tree species. Chainsaw girdling is a variant that makes a single continuous cut around the entire circumference of the tree. It has been effective for large Casuarina trees. In general, girdling is very labor-intensive and greatly reduces crew productivity. When using the hack-and-squirt technique, do not make multiple cuts directly above or below each other. This will inhibit movement of the herbicide. 
Although water- or oil-soluble formulations can be used for frill or girdle applications, water-soluble formulations are often preferred. Backpack sprayers, 1- to 2-gallon pump-up sprayers, or smaller 32-ounce spray bottles are suitable for these applications. Spray bottles should contain chemically resistant seals such as Viton.

\section{Incision Point Application}

Incision point application (IPA) is a modified version of hack-and-squirt that is new for invasive plant control. IPA utilizes a reduced number of hacks per stem and concentrated herbicide ( $100 \%$, no diluent) in very small amounts $(0.5 \mathrm{~mL} / \mathrm{hack})$ compared to traditional hack-andsquirt, frill, or girdle treatments. Herbicides recently tested for IPA in Florida include Method (aminocyclopyrachlor) and Milestone (aminopyralid). For single-stemmed trees, Method has been shown to be effective on Chinese tallow (trees up to 6 inches $\mathrm{DBH}$ ), tung (trees up to 8 inches $\mathrm{DBH}$ ), and bishopwood (trees up to 8 inches $\mathrm{DBH}$ ) with a single hack and $0.5 \mathrm{~mL}$ of $100 \%$ herbicide. Milestone has also been found to be effective on those species at similar sizes. Method has also given approximately $79 \%$ kill of melaleuca and Australian pine for trees ranging from 2-10 inches in diameter. In melaleuca, however, it is very difficult to get the small quantity of herbicide through the thick bark to the cambium without a needle injection system. More research is needed on both of these species. Limited observations suggest mimosa is also susceptible to IPA. Leadtree, a similar woody legume, was not consistently killed with this approach.

For the multi-stemmed Brazilian peppertree, both Method and Milestone are extremely effective when one hack is made on each main stem and treated with $0.5 \mathrm{~mL}$ of either herbicide. However, this can result in high application rates for individual trees with several stems, greatly limiting the number of individual multi-stemmed trees that can be treated on a per acre basis. The approach is already allowable for Method but is not yet labeled for Milestone. Research is ongoing to reduce this to fewer hacks per multi-stemmed shrub.

\section{Cut Stump Treatments}

Stump treatments are applied after cutting and removing large trees or brush. The concentrated or diluted herbicide is sprayed or painted onto the cut surface of the stump immediately after cutting. The cut surface should be as level as possible so that the herbicide solution does not run off. Sweep off dirt and sawdust that may prevent the stump from taking up the herbicide solution. The herbicide is usually applied in a band around the outer 2 inches of the entire circumference. This ensures good coverage of the phloem and cambium layer. Depending on label instructions, the entire stump is sometimes covered with dilute herbicide solution. Water- or oil-soluble formulations can be used. Spray equipment can be used as long as it contains chemical-resistant seals. Best results are obtained if the herbicide is applied no more than one hour after cutting, especially when using a water-soluble formulation. With less susceptible species, seconds can count. Oil-soluble formulations can be effective when applied after a few days; they should be applied to the sides of the stump as well. This is a hybrid cut stump plus basal bark application method.

\section{Soil Applications}

A soil application of granular herbicide formulations can be applied by handheld spreaders, specially designed blowers, or air. Soil-applied water-soluble or water-dispersible formulations can be used with the same type of equipment described for foliar applications or spotguns that can accurately deliver a measured amount of herbicide. This is generally limited to hexazinone and imazapyr for certain invasive plants. Soil applications are often reserved for very specific situations. For example, hexazinone has been used for melaleuca control in south Florida in seasonally dry areas, and imazapyr has been used for bamboo control. Both treatments will injure or kill oaks and other nontarget vegetation and should only be used in very specific conditions.

\section{Colorants: Marker Dyes and Spray Indicators}

Marker dyes and spray indicators are useful for keeping track of vegetation that has been treated when making applications to large numbers of trees or stumps. They come in a few colors including blue, red, and purple. Color contrast is most important when selecting a product. Red spray indicators may not be visible for applicators with red/ green color blindness. Cleanup is generally easier for spray indicators than for true dyes. These colorants are a useful indicator of the applicator's efficiency and precision. They are also useful for training new crew members who have not had previous experience using a backpack sprayer.

\section{Herbicide Control Methods for Invasive Non- Native Plants}

Herbicide control methods used by land managers in Florida for invasive non-native plants are listed in Table 5. All herbicides listed have been found to be effective under certain circumstances. However, many factors can affect the performance of an herbicide application; therefore, results may vary. Choice of application method, herbicide, and herbicide rate or concentration for individual species 
will depend on environmental conditions and personal experience. Treatment success may vary from site to site and sometimes even within the same site. These herbicide recommendations are not exhaustive. Imazapyr, which is highly effective for many species, is often not recommended due to significant concerns of nontarget damage.

Pesticide product labeling is the primary method of communication between an herbicide manufacturer and the herbicide users. It provides instructions on how to use the product safely and correctly. Changes in herbicide label directions may occur that are not concurrently updated in this publication. Because pesticide users are required by law to comply with all the instructions and directions for use on the pesticide label, no herbicide applications should be made based solely on information presented in this publication. Pesticide users must review and comply with all conditions set forth in the pesticide label.

NOTE: All dilutions of Garlon 4 basal bark and cut stump applications are made with an oil carrier. Original branded product names are used for convenience. Generic products that contain the same active ingredient may be available for many older active ingredients. Refer to Table 2 for active ingredients.

\section{References}

Cuda, J. P. and J. H. Frank. 2016. Florida's Established

Arthropod Weed Biological Control Agents and Their Targets. ENY-853. Gainesville: University of Florida Institute of Food and Agricultural Sciences. http://edis.ifas.ufl.edu/ in779

Dow AgroSciences. 2008. "Specimen label: Garlon ${ }^{\circledR} 4$ Ultra." Labels \& Safety Data Sheets. Accessed on July 17, 2018. https://assets.greenbook.net/16-33-15-25-08-2017ld7IN006.pdf

FLEPPC. 2017. "Florida Exotic Pest Plant Council's 2017 List of Invasive Plant Species." Florida Exotic Pest Plant Council Invasive Plant Lists. Accessed on July 17, 2018. http://bugwoodcloud.org/CDN/fleppc/ plantlists/2017/2017FLEPPCLIST-TRIFOLD-FINALAPPROVEDBYKEN-SUBMITTEDTOALTA.pdf

Loewenstein, N. J. and S. F. Enloe. 2014. “The history and use of kudzu in the southeastern United States." Alabama Cooperative Extension System. Accessed on July 17, 2018. http://www.aces.edu/pubs/docs/A/ANR-2221/ANR-2221. pdf
Shaner, D. L. (ed.) 2014. Herbicide Handbook. $10^{\text {th }}$ edition. Champaign, IL: Weed Science Society of America.

Wunderlin, R. P., B. F. Hansen, A. R. Franck, and F. B. Essig. 2018. Atlas of Florida Plants: Institute for Systematic Botany. Accessed on July 16, 2018. http://florida.plantatlas.usf.edu/ 
Table 1. Established arthropod biological control agents of invasive weeds of natural areas in Florida. Modified from Cuda and Frank (2016).

\begin{tabular}{|c|c|c|c|c|c|}
\hline Weed & Agent & Type & Origin & Date $^{1}$ & Impact \\
\hline Air potato & Lilioceris cheni & Beetle & China & 2011 & Widespread \\
\hline Brazilian peppertree & Megastigmus transvaalensis & Wasp & South Africa & Adventive & Widespread \\
\hline \multirow[t]{3}{*}{ Melaleuca } & Oxyops vitiosa & Weevil & Australia & 1997 & Widespread \\
\hline & Boreioglycaspis melaleucae & Psyllid & Australia & 2002 & Widespread \\
\hline & Lophodiplosis trifida & Fly & Australia & 2008 & Local \\
\hline \multirow[t]{2}{*}{$\begin{array}{l}\text { Old World climbing } \\
\text { fern }\end{array}$} & Neomusotima conspurcatalis & Moth & $\begin{array}{l}\text { Australia, Southeast } \\
\text { Asia }\end{array}$ & 2008 & Local \\
\hline & Floracarus perrepae & Mite & $\begin{array}{l}\text { Australia, Southeast } \\
\text { Asia }\end{array}$ & 2008 & Local \\
\hline Tropical soda apple & Gratiana boliviana & Beetle & Argentina & 2003 & Widespread \\
\hline
\end{tabular}


Table 2. Herbicides used in natural areas of Florida. ${ }^{a}$

\begin{tabular}{|c|c|c|}
\hline Product & Formulation & Comments \\
\hline Many generics & 2,4-D various & Some products may be applied directly to water. \\
\hline Method & $\begin{array}{l}\text { Aminocyclopyrachlor } \\
21.2 \% \text { SL }\end{array}$ & High degree of soil activity. Do not apply directly to water. \\
\hline Milestone & Aminopyralid $21.1 \% \mathrm{~L}$ & Do not apply directly to water. \\
\hline Fusilade II & Fluazifop $24.5 \%$ EC & Postemergence, grass-specific. Cannot be applied directly to water. \\
\hline $\begin{array}{l}\text { Glyphosate product } \\
\text { examples: } \\
\text { Roundup Custom, Rodeo, } \\
\text { AquaNeat, and many others }\end{array}$ & $\begin{array}{l}\text { Glyphosate } \\
\text { (isopropylamine salt) } \\
41.0-53.8 \% \mathrm{~L}\end{array}$ & $\begin{array}{l}\text { Use aquatic formulation for emergent vegetation control in and around water. } \\
\text { There has been a trend towards more concentrated formulations, from Roundup } \\
\text { original ( } 41 \% \text { ) to Roundup Custom and many others ( } 53.8 \% \text { ). Glyphosate product } \\
\text { recommendations in Table } 5 \text { can be applied to any glyphosate product with a \% } \\
\text { active ingredient in the } 41-53.8 \% \text { range, provided the product is appropriately } \\
\text { labeled for use. }\end{array}$ \\
\hline Velpar DF & Hexazinone $75 \%$ DF & $\begin{array}{l}\text { May cause groundwater contamination if applied to areas where soils are permeable, } \\
\text { especially where the water table is shallow. Nontarget plants can be damaged by } \\
\text { root absorption. }\end{array}$ \\
\hline Velpar L & Hexazinone $25 \% \mathrm{~L}$ & $\begin{array}{l}\text { May cause groundwater contamination if applied to areas where soils are permeable, } \\
\text { especially where the water table is shallow. Nontarget plants can be damaged by } \\
\text { root absorption. }\end{array}$ \\
\hline Plateau and generics & Imazapic $22.2 \%$ SL & Highly soil active. \\
\hline Clearcast & Imazamox $12.1 \% \mathrm{~L}$ & Can be applied directly to water. \\
\hline Arsenal, Habitat, Polaris & Imazapyr $22.6 \% \mathrm{~L}$ & $\begin{array}{l}\text { Can be applied directly to water. Nontarget plants can be damaged by root } \\
\text { absorption. }\end{array}$ \\
\hline Stalker & Imazapyr $22.6 \% \mathrm{~L}$ & $\begin{array}{l}\text { May be applied to non-irrigation ditch banks. Nontarget plants can be damaged by } \\
\text { root absorption. }\end{array}$ \\
\hline Escort XP & Metsulfuron $60 \%$ DF & $\begin{array}{l}\text { May not be applied directly to water. 24(c) SLN label for control of Old World climbing } \\
\text { fern in freshwater marshes, mesic forests, hydric forests, Everglades tree islands, and } \\
\text { Everglades prairie scrub. }\end{array}$ \\
\hline TIGR & Sethoxydim 18\% EC & 24(c) label for use on emergent aquatic grasses in water \\
\hline Trycera & Triclopyr acid $29.4 \% \mathrm{~L}$ & $\begin{array}{l}\text { Acid formulation of triclopyr. May be slightly less selective than other triclopyr } \\
\text { formulations. Aquatic use permitted. }\end{array}$ \\
\hline Brush-B-Gon Brush Killer & $\begin{array}{l}\text { Triclopyr amine } \\
8.0-8.8 \% \mathrm{~L}\end{array}$ & $\begin{array}{l}\text { Homeowner formulations readily available in retail stores. Much lower concentration } \\
\text { than Garlon } 3 \mathrm{~A} \text { and may require follow-up applications. }\end{array}$ \\
\hline $\begin{array}{l}\text { Garlon } 3 A \text {, Renovate, and } \\
\text { generics }\end{array}$ & Triclopyr amine $44.4 \% \mathrm{~L}$ & $\begin{array}{l}\text { Water-soluble triclopyr formulation for foliar and cut stump treatments. Use aquatic } \\
\text { labeled product for emergent vegetation. }\end{array}$ \\
\hline Vastlan & Triclopyr choline 39\% L & $\begin{array}{l}\text { New water-soluble formulation for foliar and cut stump treatments. Signal word } \\
\text { reduced to warning for this formulation compared to Garlon 3A and Trycera. }\end{array}$ \\
\hline Garlon 4 Ultra and generics & Triclopyr ester $61.6 \% \mathrm{~L}$ & $\begin{array}{l}\text { Oil-soluble formulation for basal bark and cut stump, but can be mixed with water } \\
\text { and used for foliar treatments. Do not apply directly to water. }\end{array}$ \\
\hline Pathfinder II & Triclopyr ester $13.6 \%$ L & $\begin{array}{l}\text { Ready-to-use oil-soluble formulation for basal bark and cut stump treatments. Do not } \\
\text { apply directly to water. }\end{array}$ \\
\hline
\end{tabular}


Table 3. Soil behavior of herbicides commonly used in natural areas of Florida (Shaner 2014).

\begin{tabular}{|l|c|l|l|}
\hline & Half-Life (days) & Mobility in Soil & \multicolumn{1}{|c|}{ Absorption by Plant Roots } \\
\hline 2,4-D amine & 10 & Moderate & Slight \\
\hline Aminocyclopyrachlor & $114-433$ & High & High \\
\hline Aminopyralid & 30 & Low & Noderate \\
\hline Fluazifop & 15 & Low & Slight \\
\hline Glyphosate & 47 & Negligible & High \\
\hline Imazapic & 120 & Moderate & Moderate \\
\hline Imazamox & $20-30$ & Low & High \\
\hline Imazapyr & $25-142$ & Mobile & High \\
\hline Hexazinone & 90 & Moderate & High \\
\hline Metsulfuron & 30 & Moderate & Slight \\
\hline Sethoxydim & 5 & Negligible & Slight \\
\hline Triclopyr & 30 & Low & \\
\hline
\end{tabular}

Table 4. Toxicity of herbicides commonly used in natural areas of Florida (Shaner 2014).

\begin{tabular}{|c|c|c|c|}
\hline & $\begin{array}{c}\text { Bobwhite Quail 8-Day } \\
\text { Dietary LD }{ }_{50}{ }^{a}\end{array}$ & $\begin{array}{l}\text { Laboratory Rat 96-Hr Oral } \\
\qquad \text { LD }_{50}{ }^{a}\end{array}$ & $\begin{array}{l}\text { Bluegill Sunfish 96-Hr } \\
\qquad \text { LC }_{50}{ }^{\mathrm{b}}\end{array}$ \\
\hline 2,4-D amine & $>5,620$ & $>1,000$ & 524 \\
\hline Aminocyclopyrachlor & $>2,075$ & $>5,000$ & $>120$ \\
\hline Aminopyralid & $>2,250$ & $>5,000$ & $>100$ \\
\hline Fluazifop & $>4,659$ (5-day) & 2,721 (Female) & 0.53 \\
\hline Glyphosate & $>4,640$ & $>5,000$ & 120 \\
\hline Hexazinone & $>10,000$ & 1,690 & 420 \\
\hline Imazapic & $>5,000$ & $>5,000$ & $>100$ \\
\hline Imazamox & $>5,572$ & $>5,000$ & 119 \\
\hline Imazapyr & $>5,000$ & $>5,000$ & $>100$ \\
\hline Metsulfuron & $>5,620$ & $>5,000$ & $>150$ \\
\hline Sethoxydim & $>5,620$ & $3,200-3,500$ & 265 \\
\hline Triclopyr amine & $>10,000$ & 2,574 & 891 \\
\hline Triclopyr ester & 9,026 & 1,581 & 0.87 \\
\hline
\end{tabular}


Table 5. Control methods in use for non-native plants by land managers in Florida. Techniques are categorized in the following order for each species: manual, cut stump (sometimes referred to as cut surface), basal bark (sometimes referred to as basal stem), foliar, and hack-and-squirt (referred to as girdle or incision point application). See the Control Methods section for additional details on these techniques.

\begin{tabular}{|c|c|c|}
\hline \multicolumn{3}{|l|}{ ACANTHACEAE (Acanthus family) } \\
\hline \multirow[t]{3}{*}{ Ruellia simplex } & & Mexican petunia \\
\hline & Treatment: & Foliar: $2-3 \%$ glyphosate product \\
\hline & Comments: & $\begin{array}{l}\text { Plants often resprout from creeping lateral roots. Multiple treatments may } \\
\text { be required. }\end{array}$ \\
\hline \multicolumn{3}{|l|}{ ANACARDIACEAE (Cashew family) } \\
\hline \multirow[t]{3}{*}{ Schinus terebinthifolia } & & Brazilian pepper \\
\hline & Treatment: & $\begin{array}{l}\text { Cut stump: } 50 \% \text { Garlon 3A, } 10 \% \text { Garlon 4, 50-100\% glyphosate product. } \\
\text { Basal bark: } 10-20 \% \text { Garlon } 4 \text { or 100\% Pathfinder II. Foliar: Garlon 4, Garlon } \\
\text { 3A, glyphosate product, Arsenal, or Habitat according to label directions. } \\
\text { Glyphosate products are less effective when used alone in spring and early } \\
\text { summer. Incision point application: one hack per stem, } 100 \% \text { Method, } 0.5 \\
\text { mL per hack. }\end{array}$ \\
\hline & Comments: & $\begin{array}{l}\text { Dioecious; female trees produce enormous quantities of bird-dispersed } \\
\text { fruit. Seed germinates readily. Some people experience allergic reactions } \\
\text { to the sap. Target only female trees if time, funds, or herbicide limitations } \\
\text { are a factor. }\end{array}$ \\
\hline \multicolumn{3}{|c|}{ APOCYNACEAE (Milkweed family) } \\
\hline Alstonia macrophylla & & Devil tree \\
\hline \multirow[t]{3}{*}{ Alstonia scholaris } & & Scholar tree; white cheesewood \\
\hline & Treatment: & Cut stump: $50 \%$ Garlon 3A. Basal bark: $10 \%$ Garlon 4 or $100 \%$ Pathfinder II. \\
\hline & Comments: & $\begin{array}{l}\text { Both species invade hammocks, pinelands, and disturbed sites. Leaves are } \\
\text { reportedly toxic to eat. A. macrophylla is becoming widespread in Miami- } \\
\text { Dade County. }\end{array}$ \\
\hline \multirow[t]{3}{*}{ Ochrosia elliptica } & & Elliptic yellowwood; ochrosia \\
\hline & Treatment: & Cut stump: 50\% Garlon 3A. \\
\hline & Comments: & $\begin{array}{l}\text { Fruits are bright red, paired, and reportedly poisonous to eat. Often used in } \\
\text { coastal landscaping. }\end{array}$ \\
\hline \multicolumn{3}{|l|}{ ARACEAE (Arum family) } \\
\hline \multirow[t]{3}{*}{ Colocasia esculenta } & & Wild taro \\
\hline & Treatment: & $\begin{array}{l}\text { Foliar: } 2.0 \% \text { Clearcast, } 1.0 \% \text { glyphosate product, } 0.5 \% \text { Renovate, } 0.5 \% \\
\text { Weedar } 64 \text {, or } 1.5 \% \text { Habitat. }\end{array}$ \\
\hline & Comments: & $\begin{array}{l}\text { Usually found in aquatic habitats, so only herbicides labeled for aquatic } \\
\text { sites can be used. Large corms (underground storage structures) make } \\
\text { control difficult. Repeat applications will be necessary. }\end{array}$ \\
\hline \multirow[t]{3}{*}{ Syngonium podophyllum } & & Arrowhead vine \\
\hline & Treatment: & $\begin{array}{l}\text { Manual: hand pull vines and remove from site or destroy (place in plastic } \\
\text { bags until decomposed). Basal stem (i.e., basal bark): } 10 \% \text { Garlon 4. Foliar: } \\
3 \% \text { Garlon } 4 \text {. Multiple treatments are required. }\end{array}$ \\
\hline & Comments: & $\begin{array}{l}\text { Breaks readily when pulled. Roots from nodes; difficult to control. Sap } \\
\text { is an irritant to skin, mouth, and eyes. Spreads vegetatively only; many } \\
\text { populations are the result of discarded landscape material. }\end{array}$ \\
\hline \multirow{3}{*}{$\begin{array}{l}\text { Epipremnum pinnatum } \\
\text { cv. aureum }\end{array}$} & & Golden pothos \\
\hline & Treatment: & Same as arrowhead vine (see above). \\
\hline & Comments: & $\begin{array}{l}\text { Roots at nodes. Sap is irritant to skin, mouth, and eyes. May form extensive } \\
\text { groundcover; leaves enlarge considerably when plants climb trees or other } \\
\text { support. Spreads vegetatively, apparently does not set seed in Florida. }\end{array}$ \\
\hline ARALIACEAE (Ginseng family) & & \\
\hline
\end{tabular}




\begin{tabular}{|c|c|c|}
\hline \multirow[t]{3}{*}{ Schefflera actinophylla } & & Queensland umbrella tree; umbrella tree \\
\hline & Treatment: & $\begin{array}{l}\text { Large individuals (>10 inches in diameter) have proven extremely difficult } \\
\text { to eradicate. Cut stump (most recommended): } 50 \% \text { Garlon } 3 \mathrm{~A} \text { or } 10 \% \\
\text { Garlon 4. Basal bark (if a cut stump treatment is not possible): } 10-20 \% \\
\text { Garlon 4. It may take up to } 9 \text { months to kill large trees. }\end{array}$ \\
\hline & Comments: & $\begin{array}{l}\text { Grows terrestrially or as an epiphyte; invasive in hammocks, particularly } \\
\text { wet, rocky sites. Bird-dispersed fruits. }\end{array}$ \\
\hline \multicolumn{3}{|l|}{ ARECACEAE (Palm family) } \\
\hline Caryota mitis & & Fishtail palm (multi-stemmed) \\
\hline \multirow[t]{3}{*}{ Caryota urens } & & Fishtail palm (solitary-trunked) \\
\hline & Treatment: & $\begin{array}{l}\text { Cut stump: cut below growing point and treat with } 50 \% \text { Garlon } 3 \mathrm{~A} \text { or } 10 \% \\
\text { Garlon } 4 \text {. Alternatively, the } 10 \% \text { Garlon } 4 \text { treatment can be applied to the } \\
\text { apical bud. This is similar to a basal bark treatment, but it is done at the } \\
\text { growing point. However, this may be difficult for large, multi-stemmed } \\
\text { clumps. }\end{array}$ \\
\hline & Comments: & $\begin{array}{l}\text { Unlike any other palm genus, the leaves are twice compound. For multiple- } \\
\text { trunked (clumping) species, when one trunk is cut, the plant will resprout; } \\
\text { fruits abundantly and is a common invasive plant in hammocks. Fruit and } \\
\text { sap are an irritant to skin, mouth, and eyes. }\end{array}$ \\
\hline \multirow[t]{3}{*}{ Chamaedorea seifrizii } & & Bamboo palm \\
\hline & Treatment: & Treat as fishtail palm, above. \\
\hline & Comments: & Pinnate-leaved, narrow-trunked, clustering species; invades hammocks. \\
\hline \multirow[t]{3}{*}{ Livistona chinensis } & & Chinese fan palm \\
\hline & Treatment: & $\begin{array}{l}\text { Manual: hand pull seedlings. Cut stump: } 10-20 \% \text { Garlon 4. Apical bud } \\
\text { treatment: } 10 \% \text { Garlon } 4 .\end{array}$ \\
\hline & Comments: & $\begin{array}{l}\text { Costapalmate leaves; green, curved, sharp spines along petiole. Can be } \\
\text { mistaken for Sabal and Thrinax species, but neither of the latter has spines } \\
\text { on the petioles. Differs from Washingtonia by having green spines and } \\
\text { lacking threadlike fiber on the leaves. }\end{array}$ \\
\hline \multirow[t]{3}{*}{ Phoenix reclinata } & & Senegal date palm \\
\hline & Treatment: & $\begin{array}{l}\text { Cut stump: } 50 \% \text { Garlon } 3 \mathrm{~A} \text { or } 10 \% \text { Garlon } 4 \text {, or apply } 10 \% \text { Garlon } 4 \text { to the } \\
\text { apical bud. }\end{array}$ \\
\hline & Comments: & $\begin{array}{l}\text { Common non-native palm in hammocks, especially near coast; pinnate } \\
\text { leaves with straight, sharp spines on petiole. Be careful as the spines may } \\
\text { pierce leather gloves and boots. }\end{array}$ \\
\hline \multirow[t]{3}{*}{ Ptychosperma elegans } & & Solitaire palm \\
\hline & Treatment: & $\begin{array}{l}\text { Manual: hand pull seedlings; cut mature trees down at ground level; } \\
\text { remove fruiting stems from site. }\end{array}$ \\
\hline & Comments: & $\begin{array}{l}\text { Pinnate leaves, solitary trunk; commonly invades hammocks; high seed } \\
\text { germination; fruit dispersed by birds, raccoons, and opossums. Very } \\
\text { common in the landscape. }\end{array}$ \\
\hline \multirow{3}{*}{$\begin{array}{l}\text { Syagrus romanzoffianum } \\
\text { (Arecastrum romanzoffianum) }\end{array}$} & & Queen palm \\
\hline & Treatment: & $\begin{array}{l}\text { Manual: hand pull seedlings; cut mature trees near the base with a } \\
\text { chainsaw. }\end{array}$ \\
\hline & Comments: & $\begin{array}{l}\text { Pinnate leaves, single trunk; common in the landscape; invasive in } \\
\text { hammocks. }\end{array}$ \\
\hline \multirow[t]{2}{*}{ Washingtonia robusta } & & Mexican fan palm, Washingtonia palm \\
\hline & Treatment: & $\begin{array}{l}\text { Manual: hand pull seedlings. Cut young specimens at ground level or } \\
\text { spray } 10-20 \% \text { Garlon } 4 \text { into apical bud. Large, mature trees in natural areas } \\
\text { should be cut down. }\end{array}$ \\
\hline
\end{tabular}




\begin{tabular}{|c|c|c|}
\hline & Comments: & $\begin{array}{l}\text { Palmate leaves with brown, curved, sharp spines along the petioles. Mature } \\
\text { trees may retain dead leaves along the trunk; leaves characteristically } \\
\text { have brown, threadlike fibers attached. Can be mistaken for Chinese } \\
\text { fan palm, Livistona chinensis, but the latter has green petiole spines and } \\
\text { costapalmate leaves. Invades pinelands and disturbed sites. }\end{array}$ \\
\hline \multicolumn{3}{|l|}{ ASTERACEAE (Aster family) } \\
\hline \multirow{3}{*}{$\begin{array}{l}\text { Sphagneticola trilobata (Wedelia } \\
\text { trilobata) }\end{array}$} & & Wedelia \\
\hline & Treatment: & $\begin{array}{l}\text { Foliar: } 0.25 \% \text { Milestone, } 2-5 \% \text { glyphosate product, or } 1.0 \% \text { Garlon } 4 \text {, with } \\
\text { follow-up treatments as needed. }\end{array}$ \\
\hline & Comments: & $\begin{array}{l}\text { Trailing species, forming dense groundcover; yellow, daisy-like flowers } \\
\text { produced all year; invades a variety of open, sunny habitats, including } \\
\text { beaches; often becomes established from discarded landscape material. }\end{array}$ \\
\hline \multicolumn{3}{|l|}{ BERBERIDACEAE (Barberry family) } \\
\hline \multirow[t]{3}{*}{ Nandina domestica } & & Heavenly bamboo \\
\hline & Treatment: & $\begin{array}{l}\text { Manual: hand pull seedlings and juveniles. Multi-stemmed clumps are } \\
\text { very difficult to hand pull. Basal bark: } 15 \% \text { Garlon } 4 \text {. Collect and destroy } \\
\text { attached fruits. }\end{array}$ \\
\hline & Comments: & Naturalized throughout the Panhandle and north central Florida. \\
\hline \multicolumn{3}{|l|}{$\begin{array}{l}\text { BIGNONIACEAE (Trumpet Creeper } \\
\text { family) }\end{array}$} \\
\hline \multirow{3}{*}{$\begin{array}{l}\text { Dolichandra unguis-cati } \\
\text { (Macfadyena unguis-cati) }\end{array}$} & & Cat's-claw vine \\
\hline & Treatment: & $\begin{array}{l}\text { Manual: hand pull new seedlings. Vines are difficult to remove from } \\
\text { trees. Cut stem (i.e., cut stump): } 100 \% \text { glyphosate product. Foliar: } 2-3 \% \\
\text { glyphosate product, } 2 \% \text { Garlon 3A. Multiple treatments will be required. }\end{array}$ \\
\hline & Comments: & $\begin{array}{l}\text { Cat's-claw vine is one of the most difficult vines to control in Florida. It } \\
\text { reestablishes from numerous seedlings with tuberous roots that typically } \\
\text { grow around the base of trees. Re-treatment will be required. }\end{array}$ \\
\hline \multicolumn{3}{|l|}{ CACTACEAE (Cactus family) } \\
\hline \multirow[t]{3}{*}{ Hylocereus undatus } & & Night-blooming cereus \\
\hline & Treatment: & $\begin{array}{l}\text { Very difficult to control when well-established on trees. Manual: hand pull } \\
\text { and remove from trees if possible; however, this plant propagates by stem } \\
\text { fragments. If complete removal is not feasible, pull as many vines down as } \\
\text { possible and spray them with } 10 \% \text { Garlon } 4 \text { or } 15 \% \text { glyphosate product. } \\
\text { Glyphosate is slow to work. }\end{array}$ \\
\hline & Comments: & $\begin{array}{l}\text { Vining cactus that climbs and roots to tree trunks; sometimes epiphytic. } \\
\text { Showy, fragrant flowers open at night in the summertime. }\end{array}$ \\
\hline \multicolumn{3}{|l|}{$\begin{array}{l}\text { CAPRIFOLIACEAE (Honeysuckle } \\
\text { family) }\end{array}$} \\
\hline \multirow[t]{3}{*}{ Lonicera japonica } & & Japanese honeysuckle \\
\hline & Treatment: & $\begin{array}{l}\text { Cut stump for large vines: } 50 \% \text { glyphosate product or } 50 \% \text { Garlon } 3 \mathrm{~A} \text {. } \\
\text { Foliar: } 3-5 \% \text { Garlon } 3 \mathrm{~A} \text { or } 1-3 \% \text { glyphosate product. }\end{array}$ \\
\hline & Comments: & $\begin{array}{l}\text { Twining or trailing woody vine with young stems pubescent. Interrupts } \\
\text { succession in once-forested areas by overtopping young trees and } \\
\text { preventing their recruitment to the overstory. Can disrupt understory } \\
\text { forest structure. May be confused with native honeysuckle, Lonicera } \\
\text { sempervirens, the stems of which are not hairy while the flowers are red } \\
\text { with yellow within. }\end{array}$ \\
\hline \multicolumn{3}{|l|}{ CASUARINACEAE (She-Oak family) } \\
\hline Casuarina equisetifolia & & Australian pine \\
\hline Casuarina glauca & & Beefwood, suckering Australian pine \\
\hline
\end{tabular}




\begin{tabular}{|c|c|c|}
\hline & Treatment: & $\begin{array}{l}\text { Basal bark: } 10-20 \% \text { Garlon } 4 \text {. Cut stump: } 50 \% \text { Garlon } 3 \text { A or } 10-20 \% \text { Garlon } \\
\text { 4. Remove scaly bark if present. Frill or girdle (for large trees): } 20 \% \text { Garlon } \\
\text { 4. Addition of } 3 \% \text { Stalker will increase consistency on older trees. Incision } \\
\text { point application: one hack for every } 6 \text { inches DBH, } 100 \% \text { Method, } 0.5 \mathrm{~mL} \\
\text { per hack. }\end{array}$ \\
\hline & Comments: & $\begin{array}{l}\text { C. equisetifolia has a single trunk and produces viable seeds that are wind- } \\
\text { and bird-dispersed; C. glauca produces suckers at the base of the trunk, } \\
\text { rarely sets seed in Florida, and has a weeping growth habit. }\end{array}$ \\
\hline \multicolumn{3}{|l|}{ CLUSIACEAE (Mangosteen family) } \\
\hline \multirow{3}{*}{$\begin{array}{l}\text { Calophyllum antillanum } \\
\text { (C. calaba; C. brasiliense var. } \\
\text { antillanum) }\end{array}$} & & Santa Maria, mast wood \\
\hline & Treatment: & $\begin{array}{l}\text { Basal bark: } 10-20 \% \text { Garlon } 4 \text {. Follow-up herbicide applications may be } \\
\text { necessary. Manual: hand pull seedlings. }\end{array}$ \\
\hline & Comments: & $\begin{array}{l}\text { Medium-sized tree with glossy, leathery leaves; has been found principally } \\
\text { invading coastal areas, including mangrove fringe. }\end{array}$ \\
\hline \multicolumn{3}{|l|}{$\begin{array}{l}\text { COMBRETACEAE (White Mangrove } \\
\text { family) }\end{array}$} \\
\hline Terminalia arjuna & & Arjun tree \\
\hline Terminalia catappa & & Indian almond \\
\hline \multirow[t]{3}{*}{ Terminalia muelleri } & & Australian almond \\
\hline & Treatment: & Cut stump: 50\% Garlon 3A. Basal bark: 10\% Garlon 4. \\
\hline & Comments: & $\begin{array}{l}\text { The Indian almond is deciduous and invades coastal habitats, hammocks, } \\
\text { and disturbed sites; arjun tree and Australian almond invade hammock } \\
\text { interiors and margins. }\end{array}$ \\
\hline \multicolumn{3}{|l|}{$\begin{array}{l}\text { COMMELINACEAE (Spiderwort } \\
\text { family) }\end{array}$} \\
\hline \multirow[t]{3}{*}{ Tradescantia fluminensis } & & Small-leaf spiderwort \\
\hline & Treatment: & Manual: hand pull small patches. Foliar: 1-2\% Garlon 3A. \\
\hline & Comments: & $\begin{array}{l}\text { Plants recover from very small fragments. Dense mats may also require re- } \\
\text { treatment. This species is exceptionally frustrating due to its rapid recovery } \\
\text { from seed. }\end{array}$ \\
\hline \multirow{3}{*}{$\begin{array}{l}\text { Tradescantia spathacea (Rhoeo } \\
\text { spathacea) }\end{array}$} & & Oyster plant \\
\hline & Treatment: & $\begin{array}{l}\text { Manual: hand pull and remove from site. Foliar: 10\% Garlon } 4 \text { applied to } \\
\text { bud. }\end{array}$ \\
\hline & Comments: & $\begin{array}{l}\text { Succulent with sword-shaped rosettes of leaves, green on upper surface, } \\
\text { bright purple on lower surface. Highly invasive, forming extensive colonies. }\end{array}$ \\
\hline \multicolumn{3}{|c|}{$\begin{array}{l}\text { CONVOLVULACEAE (Morning Glory } \\
\text { family) }\end{array}$} \\
\hline \multirow[t]{3}{*}{ Merremia tuberosa } & & Wood rose \\
\hline & Treatment: & $\begin{array}{l}\text { Cut stem (i.e., cut stump): } 50 \% \text { Garlon } 3 \mathrm{~A} \text { or } 10 \% \text { Garlon } 4 \text {. Basal bark: } 10 \% \\
\text { Garlon 4. Foliar: } 5 \% \text { glyphosate product. }\end{array}$ \\
\hline & Comments: & $\begin{array}{l}\text { Individual plants can cover extensive areas. Rarely roots at nodes. Bright } \\
\text { yellow morning glory-like flowers produced in late fall. Fruits profusely in } \\
\text { early winter; diebacks occur in late December and early January. Seeds } \\
\text { germinate readily. }\end{array}$ \\
\hline \multicolumn{3}{|c|}{ CRASSULACEAE (Stonecrop family) } \\
\hline \multirow[t]{2}{*}{ Kalanchoe pinnata } & & Life plant \\
\hline & Treatment: & $\begin{array}{l}\text { Foliar: } 5 \% \text { glyphosate product. Manual: hand pull. Glyphosate is an } \\
\text { effective treatment because it kills individual leaves that otherwise may } \\
\text { produce new plants along leaf margins. Follow-up hand removal of leaves } \\
\text { is necessary to prevent leaves from producing new plants. }\end{array}$ \\
\hline
\end{tabular}




\begin{tabular}{|c|c|c|}
\hline & Comments: & $\begin{array}{l}\text { Often found along edges of natural areas, generally as a result of discarded } \\
\text { landscape material. }\end{array}$ \\
\hline \multirow[t]{3}{*}{ Kalanchoe x houghtonii } & & Mother-of-millions \\
\hline & Treatment: & $\begin{array}{l}\text { Foliar: } 5 \% \text { glyphosate product. Manual: hand pull. Glyphosate is an } \\
\text { effective treatment because it kills individual leaves that otherwise may } \\
\text { produce new plants along leaf margins. Follow-up hand removal of leaves } \\
\text { is necessary to prevent leaves from producing new plants. }\end{array}$ \\
\hline & Comments: & Found on dunes of the Atlantic coast. \\
\hline \multicolumn{3}{|l|}{ DIOSCOREACEAE (Yam family) } \\
\hline Dioscorea alata & & Winged yam \\
\hline Dioscorea bulbifera & & Air potato \\
\hline \multirow[t]{3}{*}{ Dioscorea sansibarensis } & & Zanzibar yam \\
\hline & Treatment: & $\begin{array}{l}\text { Biological: the air potato leaf beetle, Lilioceris cheni, has been effective on } \\
\text { air potato only. Manual: cut vines that are high in trees; cut bulbils and } \\
\text { remove from site. Dig up underground tubers if possible. Foliar: 1-2\% } \\
\text { glyphosate product. Cut stem for large vines: } 10 \% \text { Garlon } 4 \text {. }\end{array}$ \\
\hline & Comments: & $\begin{array}{l}\text { Monocots with heart-shaped leaves; dieback to tubers in winter in } \\
\text { response to shortened day length, resprout in spring from tubers. All three } \\
\text { species produce aerial bulbils in late summer, early fall. }\end{array}$ \\
\hline \multicolumn{3}{|l|}{ EBENACEAE (Ebony family) } \\
\hline \multirow{3}{*}{$\begin{array}{l}\text { Diospyros digyna } \\
\text { (D. ebenum) }\end{array}$} & & Black sapote \\
\hline & Treatment: & Cut stump: $50 \%$ Garlon $3 \mathrm{~A}$. \\
\hline & Comments: & $\begin{array}{l}\text { Black bark, shiny alternate leaves; scattered throughout a few hammocks } \\
\text { in south Florida. Fruits are large, edible; green when ripe. Large individuals } \\
\text { are difficult to kill. }\end{array}$ \\
\hline \multicolumn{3}{|l|}{$\begin{array}{l}\text { ELAEAGNACEAE (Russian Olive } \\
\text { family) }\end{array}$} \\
\hline \multirow[t]{3}{*}{ Elaeagnus pungens } & & Silverthorn \\
\hline & Treatment: & Basal bark: 15\% Garlon 4. \\
\hline & Comments: & $\begin{array}{l}\text { Naturalized across much of north and central Florida. The dense, rambling } \\
\text { growth and sharp spur shoots make cutting and physical removal } \\
\text { extremely hazardous. }\end{array}$ \\
\hline \multicolumn{3}{|c|}{ EUPHORBIACEAE (Spurge family) } \\
\hline \multirow[t]{3}{*}{ Aleurites fordii (Vernicia fordii) } & & Tung tree \\
\hline & Treatment: & $\begin{array}{l}\text { Cut stump: } 50 \% \text { Garlon } 3 \text { A. Basal bark: } 20 \% \text { Garlon } 4 \text {. Incision point } \\
\text { application: one hack for every } 6 \text { inches } \mathrm{DBH}, 100 \% \text { Method, } 0.5 \mathrm{~mL} \text { per } \\
\text { hack. }\end{array}$ \\
\hline & Comments: & $\begin{array}{l}\text { Found mainly in northern counties to Citrus County. There are current } \\
\text { efforts to rebuild the historic tung oil industry in north Florida. }\end{array}$ \\
\hline \multirow[t]{3}{*}{ Bischofia javanica } & & Bishopwood; toog \\
\hline & Treatment: & $\begin{array}{l}\text { Manual: hand pull seedlings. Cut stump: } 50 \% \text { Garlon } 3 \text { A. Basal bark: } \\
\text { 10-20\% Garlon 4. Frill/girdle (large trees): } 20 \% \text { Garlon } 4 \text {. Incision point } \\
\text { application: one hack for every } 6 \text { inches DBH, } 100 \% \text { Method, } 0.5 \text { mL per } \\
\text { hack. }\end{array}$ \\
\hline & Comments: & $\begin{array}{l}\text { Dioecious; compound leaves with three large leaflets; adventitious roots } \\
\text { sometimes form along trunk in response to basal bark treatment. Female } \\
\text { trees produce massive numbers of bird-dispersed fruits that hang in grape- } \\
\text { like clusters. Target only female trees if time, funds, or herbicide limitations } \\
\text { are a factor. }\end{array}$ \\
\hline \multirow[t]{2}{*}{ Ricinus communis } & & Castor bean \\
\hline & Treatment: & $\begin{array}{l}\text { Cut stump: } 50 \% \text { Garlon } 3 \mathrm{~A} \text {. Basal bark: } 10 \% \text { Garlon } 4 \text {. Revisit site several } \\
\text { times to hand pull seedlings or treat seedlings with } 5 \% \text { glyphosate } \\
\text { product. }\end{array}$ \\
\hline
\end{tabular}




\begin{tabular}{|c|c|c|}
\hline & Comments: & High seed germination; seeds are extremely poisonous to eat. \\
\hline \multirow{3}{*}{$\begin{array}{l}\text { Triadica sebifera } \\
\text { (Sapium sebiferum) }\end{array}$} & & Chinese tallow, popcorn tree \\
\hline & Treatment: & $\begin{array}{l}\text { Cut stump: } 10 \% \text { Milestone, } 50 \% \text { Garlon } 3 \text { A or Renovate, } 20-30 \% \text { Garlon } \\
4,10 \% \text { Habitat. Basal bark: } 20 \% \text { Garlon } 4 \text { or } 100 \% \text { Pathfinder II. Addition } \\
\text { of } 3 \% \text { Stalker will reduce resprouting on older trees. Foliar: } 2 \% \text { Clearcast, } \\
0.5-0.75 \% \text { Arsenal or Habitat, } 0.5 \% \text { Method. Incision point application: one } \\
\text { hack for every } 6 \text { inches DBH, } 100 \% \text { Method, } 0.5 \mathrm{~mL} \text { per hack. Some follow- } \\
\text { up treatment may be necessary for lateral root sprouts. }\end{array}$ \\
\hline & Comments: & $\begin{array}{l}\text { Extremely aggressive tree with broad ecological tolerance. Resprouting } \\
\text { from lateral roots is common. Re-treatment for resprouts and new } \\
\text { seedlings is almost always necessary. }\end{array}$ \\
\hline \multicolumn{3}{|l|}{ FABACEAE (Pea family) } \\
\hline \multirow[t]{3}{*}{ Abrus precatorius } & & Rosary pea \\
\hline & Treatment: & $\begin{array}{l}\text { Foliar: } 0.12-0.25 \% \text { Milestone; } 5 \% \text { glyphosate product. Remove seed pods if } \\
\text { possible. Site must be revisited several times to pull seedlings. }\end{array}$ \\
\hline & Comments: & Seeds are black and red and highly poisonous. \\
\hline \multirow[t]{3}{*}{ Acacia auriculiformis } & & Earleaf acacia \\
\hline & Treatment: & Cut stump: 50\% Garlon 3A, 10\% Milestone. Basal bark: 10\% Garlon 4. \\
\hline & Comments: & A frequent invader of pinelands and disturbed sites. \\
\hline \multirow[t]{3}{*}{ Adenanthera pavonina } & & Red sandalwood \\
\hline & Treatment: & $\begin{array}{l}\text { Cut stump: } 50 \% \text { Garlon 3A, } 10 \% \text { Milestone, or } 10 \% \text { Garlon } 4 \text {. Basal bark: } \\
10 \% \text { Garlon } 4 . \text { Manual: small seedlings can be hand pulled. }\end{array}$ \\
\hline & Comments: & $\begin{array}{l}\text { Can be confused with Albizia lebbeck, which has larger leaflets. Bark of red } \\
\text { sandalwood is typically reddish; produces hard, red seeds that may persist } \\
\text { in soil for up to } 5 \text { years. }\end{array}$ \\
\hline \multirow[t]{3}{*}{ Albizia lebbeck } & & Woman's tongue \\
\hline & Treatment: & $\begin{array}{l}\text { Cut stump: } 50 \% \text { Garlon } 3 \mathrm{~A}, 10 \% \text { Milestone, or } 10 \% \text { Garlon } 4 \text {. Basal bark: } \\
20 \% \text { Garlon } 4 \text { or } 100 \% \text { Pathfinder II. Follow-up treatments necessary for } \\
\text { root sprouts with } 10 \% \text { Garlon } 4 \text {. }\end{array}$ \\
\hline & Comments: & $\begin{array}{l}\text { Large, dry, brown pods with few large seeds; mature principally in winter. } \\
\text { Common in pinelands and hammocks. }\end{array}$ \\
\hline \multirow[t]{3}{*}{ Albizia julibrissin } & & Mimosa \\
\hline & Treatment: & $\begin{array}{l}\text { Cut stump: } 50 \% \text { Garlon 3A, 10\% Milestone. Basal bark: } 15 \% \text { Garlon } 4 \text { or } \\
100 \% \text { Pathfinder II. }\end{array}$ \\
\hline & Comments: & $\begin{array}{l}\text { Apply to } 1-2 \text { feet of trunk on larger trees. Trees with a diameter greater } \\
\text { than } 3 \text { inches may require re-treatment. }\end{array}$ \\
\hline Bauhinia aculeata & & White orchid tree \\
\hline Bauhinia purpurea & & Purple orchid tree \\
\hline \multirow[t]{3}{*}{ Bauhinia variegata } & & Orchid tree \\
\hline & Treatment: & Cut stump: 50\% Garlon 3A. Basal bark: 10\% Garlon 4. \\
\hline & Comments: & $\begin{array}{l}\text { All three species invade disturbed sites and the edges of natural areas in } \\
\text { Miami-Dade County. }\end{array}$ \\
\hline \multirow[t]{3}{*}{ Dalbergia sissoo } & & Indian rosewood \\
\hline & Treatment: & Cut stump: 50\% Garlon 3A, 10\% Milestone. Basal bark: 10\% Garlon 4. \\
\hline & Comments: & $\begin{array}{l}\text { Medium to large tree with compound leaves bearing } 3 \text { to } 5 \text { leaflets. Papery } \\
\text { seed pods are wind-dispersed. Invasive along hammock margin, canopy } \\
\text { gaps, and disturbed sites. }\end{array}$ \\
\hline \multirow[t]{2}{*}{ Delonix regia } & & Royal poinciana \\
\hline & Treatment: & $\begin{array}{l}\text { Basal bark: } 20 \% \text { Garlon } 4 \text { or } 100 \% \text { Pathfinder II. Cut stump: } 50 \% \text { Garlon } 3 \mathrm{~A} \text {, } \\
10 \% \text { Milestone. }\end{array}$ \\
\hline
\end{tabular}




\begin{tabular}{|c|c|c|}
\hline & Comments: & $\begin{array}{l}\text { Large spreading tree with bipinnately compound leaves; very popular } \\
\text { flowering tree in the landscape. Invades hammock margin, canopy gaps, } \\
\text { and disturbed sites; seeds commonly sprout beneath parent trees. }\end{array}$ \\
\hline \multirow[t]{3}{*}{ Indigofera suffruticosa } & & Anil indigo, anil de pasto, wild indigo, West Indian indigo \\
\hline & Treatment: & Foliar: 1\% Garlon 4, 0.15\% Milestone. \\
\hline & Comments: & $\begin{array}{l}\text { An erect branching shrub growing to } 3 \text { feet tall with pinnate leaves. } \\
\text { Commonly found growing in dry, highly disturbed areas and hammocks. }\end{array}$ \\
\hline \multirow[t]{3}{*}{ Leucaena leucocephala } & & Lead tree, jumbie bean \\
\hline & Treatment: & $\begin{array}{l}\text { Difficult to control. Variable results have been reported. Cut stump: } 50 \% \\
\text { Garlon } 3 \mathrm{~A}, 10 \% \text { Milestone. Basal bark or cut stem: } 10-20 \% \text { Garlon } 4 \text { has } \\
\text { been reported to be effective; others report only partial success with } \\
\text { higher rates. } 25 \% \text { has been effective on trees with a diameter under } 3 \\
\text { inches, but larger trees were not killed. Large trees must be completely } \\
\text { girdled for frill/girdle applications. Foliar: } 0.25 \% \text { Milestone. }\end{array}$ \\
\hline & Comments: & $\begin{array}{l}\text { Usually found on edges of natural areas; can be mistaken for native wild } \\
\text { tamarind, Lysiloma latisiliquum. }\end{array}$ \\
\hline \multirow[t]{3}{*}{ Mimosa pigra } & & Catclaw mimosa \\
\hline & Treatment: & $\begin{array}{l}\text { Cut stump: } 50 \% \text { Garlon } 3 \text { A, } 10 \% \text { Milestone. Basal bark: } 30 \% \text { Garlon } 4 \text {. Foliar: } \\
0.25 \% \text { Milestone. Repeat applications of } 1.5 \% \text { glyphosate product or } 2-3 \% \\
\text { Garlon } 3 \text { A or Renovate. }\end{array}$ \\
\hline & Comments: & $\begin{array}{l}\text { Repeated site visits are necessary to control seedlings and prevent further } \\
\text { seed production. Approximately ten years are needed for seed bank } \\
\text { eradication. }\end{array}$ \\
\hline \multirow[t]{3}{*}{ Mucuna pruriens } & & Cow itch; velvet bean \\
\hline & Treatment: & $\begin{array}{l}\text { Manual: hand pull mature vines and seedlings; does not resprout from } \\
\text { roots. It is important to continue pulling seedlings until seed bank is } \\
\text { exhausted. Basal bark: } 10 \% \text { Garlon } 4 \text {. Foliar: } 5 \% \text { glyphosate product, } 0.25 \% \\
\text { Milestone. }\end{array}$ \\
\hline & Comments: & Hairs on seed pods can cause intense itching. \\
\hline \multirow{3}{*}{$\begin{array}{l}\text { Pueraria montana var. lobata }(P . \\
\text { lobata) }\end{array}$} & & Kudzu \\
\hline & Treatment: & $\begin{array}{l}\text { Foliar: } 0.25 \% \text {, Milestone, } 0.5 \% \text { Method, } 2 \% \text { Garlon } 3 \mathrm{~A}, 2 \% \text { glyphosate } \\
\text { product. Treat when actively growing. }\end{array}$ \\
\hline & Comments: & $\begin{array}{l}\text { Follow-up treatments are necessary as resprouting occurs from root } \\
\text { crowns. }\end{array}$ \\
\hline \multirow[t]{3}{*}{ Wisteria sinensis } & & Chinese wisteria \\
\hline & Treatment: & $\begin{array}{l}\text { Cut stump: } 10 \% \text { Milestone, } 100 \% \text { Garlon } 3 \mathrm{~A} \text {. Basal bark: } 20-30 \% \text { Garlon } 4 \text {. } \\
\text { Multiple treatments may be required to control prolific lateral root sprouts. }\end{array}$ \\
\hline & Comments: & $\begin{array}{l}\text { High-climbing woody vine with showy lavender flowers in spring. Can top } \\
\text { and kill mature trees. Legume densely, velvety pubescent compared to the } \\
\text { native Wisteria frutescens, with glabrous fruits. }\end{array}$ \\
\hline \multicolumn{3}{|l|}{ GOODENIACEAE (Goodenia family) } \\
\hline \multirow{3}{*}{$\begin{array}{l}\text { Scaevola taccada var. sericea } \\
\text { (S. taccada) }\end{array}$} & & Beach naupaka; half flower \\
\hline & Treatment: & $\begin{array}{l}\text { Manual: hand pull at least fruit from site whenever possible. Basal } \\
\text { bark: } 10 \% \text { Garlon } 4 \text {. Cut stump: } 50 \% \text { Garlon } 3 \text { A or } 10 \% \text { Garlon } 4 \text {. Foliar } \\
\text { (monocultures): } 4 \% \text { Garlon } 4 \text {. }\end{array}$ \\
\hline & Comments: & $\begin{array}{l}\text { Semi-woody shrub with either glabrous or pubescent, somewhat succulent } \\
\text { leaves. Flowers are fan-shaped, white or blushed with purple; fruit are } \\
\text { white, which help distinguish it from the black-fruited native inkberry, } \\
\text { Scaevola plumieri. Seeds of the exotic Scaevola are carried by ocean } \\
\text { currents where they sprout and colonize beaches and other shoreline } \\
\text { habitats. Branches in contact with ground may root. Seed bank lasts one } \\
\text { year. }\end{array}$ \\
\hline
\end{tabular}




\begin{tabular}{|c|c|c|}
\hline \multicolumn{3}{|l|}{ LAMIACEAE (Mint family) } \\
\hline \multirow[t]{3}{*}{ Vitex rotundifolia } & & Beach vitex \\
\hline & Treatment: & $\begin{array}{l}\text { Cut stem (i.e., cut stump): } 50 \% \text { v/v glyphosate product, } 50 \% \text { Habitat, } 50 \% \\
\text { Garlon } 3 \mathrm{~A} \text {. Habitat is the most effective, but care must be taken to prevent } \\
\text { nontarget damage. Re-treatment may be required to control new sprouts } \\
\text { from buried stems and new seedlings. }\end{array}$ \\
\hline & Comments: & $\begin{array}{l}\text { A salt-tolerant, woody plant that forms low-growing thickets on beaches } \\
\text { and dunes. Its sprawling branches that run for many meters while rooting } \\
\text { at the nodes enable this species to thrive in coastal dune environments. }\end{array}$ \\
\hline \multicolumn{3}{|l|}{ LAURACEAE (Laurel family) } \\
\hline \multirow[t]{3}{*}{ Cinnamomum camphora } & & Camphor tree \\
\hline & Treatment: & Cut stump: 50\% Garlon 3A. Basal bark: 20\% Garlon 4. \\
\hline & Comments: & $\begin{array}{l}\text { Leaves exhibit a strong camphor odor when crushed. Abundant in north } \\
\text { and central Florida. }\end{array}$ \\
\hline \multicolumn{3}{|l|}{$\begin{array}{l}\text { LYGODIACEAE (Climbing Fern } \\
\text { family) }\end{array}$} \\
\hline \multirow[t]{3}{*}{ Lygodium microphyllum } & & Old World climbing fern \\
\hline & Treatment: & $\begin{array}{l}\text { Foliar: for ground applications, cut plants that grow high into trees; } \\
\text { thoroughly spray foliage to wet with } 2-3 \% \text { glyphosate product, } 2 \% \text { Garlon } \\
3 \mathrm{~A}, 1 \% \text { Plateau, or equivalent of } 2 \text { ounces Escort XP/100 gallon diluent. For } \\
\text { light infestations, use } 2-4 \% \text { glyphosate product. For aerial application, } 7.5 \\
\text { pints glyphosate product or } 2 \text { ounces Escort XP in sufficient volume, using } \\
\text { a spray pattern to maximize coverage. }\end{array}$ \\
\hline & Comments: & $\begin{array}{l}\text { Fern with twining, climbing fronds, leaflets unlobed. The most serious } \\
\text { natural area weed in Florida. Land managers should be on constant } \\
\text { lookout for it and take immediate steps to control it when encountered. }\end{array}$ \\
\hline \multirow[t]{3}{*}{ Lygodium japonicum } & & Japanese climbing fern \\
\hline & Treatment: & Foliar: 2\% glyphosate product. Plateau 40 oz/100 gal. \\
\hline & Comments: & $\begin{array}{l}\text { Fern with twining, climbing fronds, leaflets lobed. Occurs throughout } \\
\text { west and north Florida, moving into central Florida. Smothers seedlings of } \\
\text { overstory tree species. }\end{array}$ \\
\hline \multicolumn{3}{|l|}{ MALVACEAE (Mallow family) } \\
\hline \multirow{3}{*}{$\begin{array}{l}\text { Talipariti tiliaceum var. tiliaceum } \\
\text { (Hibiscus tiliaceus) }\end{array}$} & & Sea hibiscus; mahoe \\
\hline & Treatment: & $\begin{array}{l}\text { Manual: hand pull seedlings. Basal bark: } 10-20 \% \text { Garlon 4. Cut stump: } 50 \% \\
\text { Garlon 3A. }\end{array}$ \\
\hline & Comments: & $\begin{array}{l}\text { Multi-trunked, large, spreading tree with long-petioled, rounded cordate } \\
\text { leaves. Hibiscus-like yellow flowers turn pink or red with age; seeds float } \\
\text { and drift to new coastal habitats. Erroneously considered native by some } \\
\text { people. }\end{array}$ \\
\hline \multirow[t]{3}{*}{ Thespesia populnea } & & Seaside mahoe; portia tree \\
\hline & Treatment: & $\begin{array}{l}\text { Manual: seedlings can be hand pulled. Basal bark: 10-25\% Garlon 4. Cut } \\
\text { stump: } 50 \% \text { Garlon 3A. }\end{array}$ \\
\hline & Comments: & $\begin{array}{l}\text { Multi-trunked, large, spreading tree; heart-shaped leaves with a } \\
\text { pronounced drip tip. Hibiscus-like yellow flowers turn pink or red with age; } \\
\text { seeds float and drift to new coastal habitats. Erroneously considered native } \\
\text { by some people. }\end{array}$ \\
\hline \multirow[t]{3}{*}{ Urena lobata } & & Caesar weed, cadillo \\
\hline & Treatment: & $\begin{array}{l}\text { Foliar applications of } 1 \% 2,4-\mathrm{D}, 1 \% \text { Garlon } 4,1 \% \text { Vista XRT, or } 0.15 \% \\
\text { Milestone ( } 1 \mathrm{fl} \text { oz per } 5 \text { gallons of water) are effective, even on mature } \\
\text { plants. }\end{array}$ \\
\hline & Comments: & $\begin{array}{l}\text { Undershrub growing from } 1.5 \text { to } 8 \text { feet in height. Leaves are shallowly } 3 \text { - to } \\
\text { 5-lobed with the upper surface coated in rough hairs. Barbed fruits stick to } \\
\text { clothing and fur, aiding in dispersal. }\end{array}$ \\
\hline
\end{tabular}




\begin{tabular}{|c|c|c|}
\hline \multicolumn{3}{|c|}{ MELIACEAE (Mahogany family) } \\
\hline \multirow[t]{3}{*}{ Melia azedarach } & & Chinaberry, Pride of India \\
\hline & Treatment: & $\begin{array}{l}\text { Cut stump: } 10 \% \text { Method, } 50 \% \text { Garlon } 3 \text { A. Basal bark: } 10 \% \text { Method, } 15-30 \% \\
\text { Garlon } 4 \text {. Addition of 3\% Stalker to Garlon } 4 \text { may increase consistency. } \\
\text { Foliar: } 0.25 \% \text { Method. }\end{array}$ \\
\hline & Comments: & $\begin{array}{l}\text { Often shrubby and root-suckering, forming thickets. Fruits poisonous to } \\
\text { humans and some other mammals. Most abundantly found in north and } \\
\text { west Florida, but often escapes cultivation in peninsular counties south to } \\
\text { the Keys. }\end{array}$ \\
\hline \multicolumn{3}{|c|}{ MORACEAE (Mulberry family) } \\
\hline \multirow[t]{3}{*}{ Broussonetia papyrifera } & & Paper mulberry \\
\hline & Treatment: & $\begin{array}{l}\text { Basal bark: } 20-30 \% \text { Garlon } 4 \text {. Addition of 3\% Stalker will increase } \\
\text { consistency. }\end{array}$ \\
\hline & Comments: & $\begin{array}{l}\text { Large tree with scabrous leaves and reddish-orange balls of flowers. } \\
\text { Invades hammocks and disturbed sites. Young trees can be mistaken for } \\
\text { the native red mulberry, Morus rubra. }\end{array}$ \\
\hline Ficus altissima & & Lofty fig \\
\hline Ficus benghalensis & & Banyan fig \\
\hline \multirow[t]{3}{*}{ Ficus microcarpa } & & Laurel fig \\
\hline & Treatment: & Basal bark: 10\% Garlon 4. \\
\hline & Comments: & $\begin{array}{l}\text { All three species invade the interior and edges of hammocks; often found } \\
\text { growing as epiphytes (on trees) or epiliths (on rocks or stone structures). } \\
\text { Exercise care when treating epiphytic figs to ensure the herbicide does not } \\
\text { come in contact with the host tree. All Ficus species are very sensitive to } \\
\text { Garlon } 4 \text {. Extreme care must be taken when treating any vegetation near } \\
\text { the native strangler fig and native shortleaf fig. Overspray that contacts } \\
\text { surface roots can kill a large Ficus tree. }\end{array}$ \\
\hline \multicolumn{3}{|c|}{ MYRSINACEAE (Myrsine family) } \\
\hline \multirow{3}{*}{$\begin{array}{l}\text { Ardisia elliptica } \\
\text { (Ardisia solanacea) }\end{array}$} & & Shoebutton ardisia \\
\hline & Treatment: & $\begin{array}{l}\text { Manual: hand pull seedlings. Cut stump: 50\% Garlon 3A. Basal bark: 10\% } \\
\text { Garlon } 4 .\end{array}$ \\
\hline & Comments: & $\begin{array}{l}\text { Often found in wetter areas; prolific reproduction; closely resembles the } \\
\text { native Ardisia escallonioides (marlberry), but differs in that new growth, } \\
\text { petioles, and stem tips are pink to red, and fruit are produced in axillary, } \\
\text { not terminal, clusters. }\end{array}$ \\
\hline \multirow[t]{3}{*}{ Ardisia crenata } & & Coral ardisia \\
\hline & Treatment: & $\begin{array}{l}\text { Basal bark: } 10 \% \text { Garlon } 4 \text {. Foliar: } 3 \% \text { Garlon } 3 \mathrm{~A} \text {. The addition of } 1 \% \text { Plateau } \\
\text { to Garlon } 3 \mathrm{~A} \text { as a foliar treatment may provide preemergent suppression of } \\
\text { new seedlings for several months. }\end{array}$ \\
\hline & Comments: & $\begin{array}{l}\text { Small shrub, easily recognized by shiny, leathery leaves, with scalloped } \\
\text { margins, calluses in the margin notches, and persistent bright red } \\
\text { (sometimes white) fruits. }\end{array}$ \\
\hline \multicolumn{3}{|l|}{ MYRTACEAE (Myrtle family) } \\
\hline \multirow[t]{3}{*}{ Eugenia uniflora } & & Surinam cherry \\
\hline & Treatment: & $\begin{array}{l}\text { Basal bark: for plants up to } 0.5 \text {-inch diameter, } 10 \% \text { Garlon } 4 \text {. Cut stump: } \\
50 \% \text { Garlon } 3 \text { A or } 10 \% \text { Garlon } 4 \text {. Seedlings should be hand pulled. }\end{array}$ \\
\hline & Comments: & Leaves have a distinct odor when crushed. \\
\hline Melaleuca quinquenervia & & Punk tree; melaleuca \\
\hline
\end{tabular}




\begin{tabular}{|c|c|c|}
\hline & Treatment: & $\begin{array}{l}\text { Manual: seedlings and saplings can be hand pulled (taking care not to } \\
\text { break the plant off the root system), then removed off site or placed in } \\
\text { piles to reduce the chance of re-rooting. Foliar: } 5 \% \text { glyphosate product } \\
\text { (seedlings and saplings only). Aerial application of } 3 \text { quarts glyphosate } \\
\text { product }+3 \text { quarts Arsenal + } 4 \text { quarts methylated seed oil per acre. } \\
\text { Follow-up ground or aerial application may be necessary. Cut stump: } \\
10-25 \% \text { Arsenal or Habitat, } 50-100 \% \text { glyphosate product, or } 40 \% \\
\text { glyphosate product }+10 \% \text { Arsenal or Habitat. Use of imazapyr provides } \\
\text { more consistent results. Frill and girdle: } 20-50 \% \text { Arsenal or Habitat or } 10 \% \\
\text { Arsenal or Habitat }+40 \% \text { glyphosate product. }\end{array}$ \\
\hline & Comments: & $\begin{array}{l}\text { Tall, highly invasive tree in freshwater wetlands; thick, papery bark; } \\
\text { extremely high seed production; seed dispersed by wind following natural } \\
\text { or mechanical disturbance. }\end{array}$ \\
\hline \multirow[t]{3}{*}{$\begin{array}{l}\text { Psidium guajava } \\
\text { Psidium cattleianum }\end{array}$} & & $\begin{array}{l}\text { Common guava } \\
\text { Strawberry guava }\end{array}$ \\
\hline & Treatment: & Basal bark or cut stump: $10 \%$ Garlon 4. \\
\hline & Comments: & $\begin{array}{l}\text { Indigenous to Central and South America, this commercial fruit crop is a } \\
\text { common invader in disturbed areas, hammock margins, and wetlands. }\end{array}$ \\
\hline \multirow[t]{3}{*}{ Rhodomyrtus tomentosa } & & Downy rose myrtle \\
\hline & Treatment: & $\begin{array}{l}\text { Basal bark or cut stump (individual plants): } 10-20 \% \text { Garlon } 4 \text {. Re-treatment } \\
\text { may be necessary. Foliar: } 1 \% \text { Arsenal }+2 \% \text { glyphosate product or } 2 \text { quarts } \\
\text { Vanquish/acre in } 50 \text {-gallon spray volume. }\end{array}$ \\
\hline & Comments: & $\begin{array}{l}\text { A very aggressive evergreen shrub growing to } 6 \text { feet tall found as far north } \\
\text { as Pasco County. Action should be taken immediately to remove it when } \\
\text { found in natural areas. Identified by opposite, simple entire leaves, which } \\
\text { are glossy green above and densely soft-hairy below, with three main veins } \\
\text { from the blade base. Round, dark purple fruit with sweetly aromatic flesh. }\end{array}$ \\
\hline Syzygium cumini & & Jambolan plum; Java plum \\
\hline \multirow[t]{3}{*}{ Syzygium jambos } & & Rose apple \\
\hline & Treatment: & $\begin{array}{l}\text { Cut stump: } 50 \% \text { Garlon } 3 \text { A or } 20 \% \text { Garlon } 4 \text {. Basal bark: } 20 \% \text { Garlon } 4 \text { or } \\
\text { Pathfinder II. Mature trees may take up to } 9 \text { months to die. }\end{array}$ \\
\hline & Comments: & Large ornamental trees producing bird- and mammal-dispersed fruits. \\
\hline \multicolumn{3}{|l|}{ OLEACEAE (Olive family) } \\
\hline Jasminum dichotomum & & Gold Coast jasmine \\
\hline \multirow[t]{3}{*}{ Jasminum fluminense } & & Brazilian jasmine \\
\hline & Treatment: & $\begin{array}{l}\text { Cut stump: } 50 \% \text { Garlon } 3 \mathrm{~A} \text { or } 10 \% \text { Garlon } 4 \text {. Basal bark: } 10 \% \text { Garlon } 4 \text {. It is } \\
\text { helpful to pull runners back to the main stem, cut, and apply Garlon } 3 \mathrm{~A} \text { or } \\
\text { Garlon } 4 \text { to the cut stem. Re-treatment of areas is usually necessary. Foliar: } \\
5 \% \text { glyphosate product. Manual: newly emerged seedlings can be hand } \\
\text { pulled. }\end{array}$ \\
\hline & Comments: & $\begin{array}{l}\text { Jasmines produce a large number of bird- and mammal-dispersed seeds } \\
\text { that germinate readily; highly invasive. }\end{array}$ \\
\hline Ligustrum lucidum & & Glossy privet \\
\hline \multirow[t]{3}{*}{ Ligustrum sinense } & & Chinese privet \\
\hline & Treatment: & $\begin{array}{l}\text { Cut stump: } 25 \% \text { Garlon } 3 \mathrm{~A} \text { or } 25 \% \text { glyphosate product. Basal bark: } 15-20 \% \\
\text { Garlon } 4 \text { or } 100 \% \text { Pathfinder II. Foliar: } 3-5 \% \text { glyphosate product. Foliar } \\
\text { treatment is most effective in the late fall and early winter. }\end{array}$ \\
\hline & Comments: & $\begin{array}{l}\text { L. sinense widespread in northern Florida mesic woods, road shoulders, and } \\
\text { hedgerows. L. lucidum often found in urban forests. Both are dispersed by } \\
\text { mammals, birds, and floodwaters. }\end{array}$ \\
\hline \multicolumn{3}{|c|}{$\begin{array}{l}\text { ONAGRACEAE (Evening Primrose } \\
\text { family) }\end{array}$} \\
\hline \multirow[t]{3}{*}{ Ludwigia peruviana } & & Peruvian water primrose \\
\hline & Treatment: & Foliar: $2 \%$ Garlon 3A; $1 \%$ Habitat; $2 \%$ Clearcast \\
\hline & Comments: & Increasingly problematic in many wet areas. \\
\hline
\end{tabular}




\begin{tabular}{|c|c|c|}
\hline $\begin{array}{l}\text { PASSIFLORACEAE (Passionflower } \\
\text { family) }\end{array}$ & & \\
\hline \multirow[t]{3}{*}{ Passiflora edulis } & & Passionflower \\
\hline & Treatment: & Cut stump: $50 \%$ Garlon 3 A or $10 \%$ Garlon 4. Basal bark: $10 \%$ Garlon 4. \\
\hline & Comments: & $\begin{array}{l}\text { Commercially cultivated worldwide, this South American subtropical } \\
\text { species closely resembles the native purple passionflower } P \text {. incarnata, } \\
\text { which differs by having dull rather than lustrous upper leaf surfaces. } \\
\text { Invasive in hammocks. }\end{array}$ \\
\hline \multicolumn{3}{|l|}{ PIPERACEAE (Pepper family) } \\
\hline $\begin{array}{l}\text { Piper umbellatum (Lepianthes } \\
\text { umbellata) }\end{array}$ & & Baquina \\
\hline Piper aduncum & & Bamboo piper, spiked pepper, false matico \\
\hline \multirow[t]{3}{*}{ Piper auritum } & & Vera Cruz pepper, makulan \\
\hline & Treatment: & $\begin{array}{l}\text { Manual: hand pull when possible (broken roots may resprout). Cut stump: } \\
50 \% \text { Garlon } 3 \text { A. Basal bark: } 20 \% \text { Garlon } 4 \text { or } 100 \% \text { Pathfinder II. Remove cut } \\
\text { stems from the site to avoid resprouting from nodes. }\end{array}$ \\
\hline & Comments: & $\begin{array}{l}\text { All three species invade hardwood hammocks, especially margins and } \\
\text { canopy gaps. }\end{array}$ \\
\hline \multicolumn{3}{|l|}{ POACEAE (Grass family) } \\
\hline \multirow[t]{3}{*}{ Imperata cylindrica } & & Cogongrass \\
\hline & Treatment: & $\begin{array}{l}\text { Foliar: 3-4 quarts glyphosate product, } 2-3 \text { quarts Arsenal, or } 0.5 \text { quarts } \\
\text { Fusilade per acre. For high-volume spot treatment, use 3-5\% glyphosate } \\
\text { product or } 0.25-0.5 \% \text { Arsenal. Herbicides should be used in combination } \\
\text { with burning or tillage for optimum control. See EDIS document SS-AGR-52 } \\
\text { (http://edis.ifas.ufl.edu/wg202) for additional information. }\end{array}$ \\
\hline & Comments: & $\begin{array}{l}\text { If not controlled, cogongrass will spread along roadways and into pastures, } \\
\text { mining areas, forestland, parks, and other recreation areas. Extensive } \\
\text { rhizomes must be eliminated for long-term control. }\end{array}$ \\
\hline \multirow[t]{3}{*}{ Melinis repens } & & Natal grass, rose Natal grass \\
\hline & Treatment: & $\begin{array}{l}\text { Foliar applications of } 2-3 \text { quarts per acre or } 1-2 \% \text { v/v glyphosate; } 0.5-1 \\
\text { quart per acre or } 0.5-1 \% \text { v/v imazapyr. Hexazinone at } 1-2 \text { quarts per acre is } \\
\text { also effective. Imazapic (Plateau, Impose, others) at } 12 \text { oz per acre for seed } \\
\text { suppression. }\end{array}$ \\
\hline & Comments: & $\begin{array}{l}\text { New seedlings are common following glyphosate treatment. Imazapyr and } \\
\text { hexazinone provide some residual control, but may prevent recovery of } \\
\text { desirable native species. Imazapic can be used to reduce seed production } \\
\text { and provide better selectivity to native species. }\end{array}$ \\
\hline \multirow[t]{3}{*}{ Neyraudia reynaudiana } & & Burma reed, silk reed \\
\hline & Treatment: & $\begin{array}{l}\text { Foliar: } 1-3 \% \text { glyphosate product. Cut stem: } 10 \% \text { Garlon } 4 . \text { In areas with } \\
\text { surrounding desirable vegetation, the culms can be cut to ground level } \\
\text { and sprayed with } 5 \% \text { glyphosate product when the plant reaches a } \\
\text { height of approximately } 12 \text { to } 18 \text { inches (cut stems should be removed } \\
\text { from the site). Removing seedheads before treatment will reduce need } \\
\text { for follow-up. Responds quickly after fire and should be targeted as soon } \\
\text { as new growth reaches } 12 \text { to } 18 \text { inches. Most native plants will not have } \\
\text { resprouted from the fire by the time Burma reed has reached this height, } \\
\text { and it can be easily treated with little concern about nontarget damage. }\end{array}$ \\
\hline & Comments: & $\begin{array}{l}\text { Tall cane grass; extremely invasive in pine rockland habitat, open, dry } \\
\text { habitats, roadsides, vacant lots, and other disturbed sites. Fire-tolerant. }\end{array}$ \\
\hline \multirow[t]{3}{*}{ Panicum repens } & & Torpedograss \\
\hline & Treatment: & $\begin{array}{l}\text { Foliar: } 0.75-1.5 \% \text { glyphosate product and/or } 0.5 \% \text { Habitat, } 4 \text { pints Habitat } \\
\text { per acre, or } 5 \% \text { glyphosate product spot treatment. }\end{array}$ \\
\hline & Comments: & $\begin{array}{l}\text { Numerous dormant buds associated with extensive rhizomes make this } \\
\text { plant extremely difficult to control. Several years of reapplication may be } \\
\text { necessary to completely eliminate a population. }\end{array}$ \\
\hline
\end{tabular}




\begin{tabular}{|c|c|c|}
\hline \multirow{3}{*}{$\begin{array}{l}\text { Pennisetum purpureum (Cenchrus } \\
\text { purpureus) }\end{array}$} & & Napier grass \\
\hline & Treatment: & $\begin{array}{l}\text { Foliar: } 1-3 \% \text { glyphosate product. If nontarget damage is a concern, cut } \\
\text { stems to ground level and allow sprouts to reach } 8-12 \text { inches and treat } \\
\text { the same as Neyraudia. Broadcast 3-5 quarts/acre glyphosate product, } 2 \\
\text { quarts/acre Arsenal, or } 1 \text { quart Arsenal and } 2 \text { quarts glyphosate product. }\end{array}$ \\
\hline & Comments: & $\begin{array}{l}\text { Tall cane grass with white stripe down the center of the leaf blade and a } \\
\text { foxtail-like inflorescence; prefers wetter substrates. }\end{array}$ \\
\hline \multirow[t]{3}{*}{ Phyllostachys aurea } & & Golden bamboo \\
\hline & Treatment: & $\begin{array}{l}\text { Foliar: cut mature plants, allow to regrow to } 3 \text { to } 4 \text { feet, and apply } 5 \% \\
\text { glyphosate product or } 2 \% \text { Arsenal or Habitat. }\end{array}$ \\
\hline & Comments: & $\begin{array}{l}\text { Not a common problem, but can spread extensively once established. } \\
\text { Populations should be controlled immediately. Can become established } \\
\text { through dumping of yard waste. }\end{array}$ \\
\hline \multirow[t]{3}{*}{ Sporobolus jacquemontii } & & Giant smutgrass, West Indian dropseed \\
\hline & Treatment: & $\begin{array}{l}\text { Broadcast applications of hexazinone (Velpar, Tide Hexazinone, Velossa) } \\
\text { at } 2 \text { quarts per acre during the rainy season (July-September). Spot } \\
\text { application of 1-2\% glyphosate product is effective. }\end{array}$ \\
\hline & Comments: & $\begin{array}{l}\text { Plants should be actively growing for optimum activity with either } \\
\text { herbicide. }\end{array}$ \\
\hline \multirow[t]{3}{*}{ Urochloa mutica (Brachiaria mutica) } & & Para grass \\
\hline & Treatment: & $\begin{array}{l}\text { Foliar applications of glyphosate at 3-4 quarts per acre or imazapyr } \\
\text { (Arsenal, Habitat) at } 2-3 \text { quarts per acre. Spot treatments containing } 3 \% \\
\text { glyphosate or } 0.5-1 \% \text { imazapyr are effective. A more selective option is } \\
\text { TIGR, which can be broadcast at } 40 \text { oz/A or applied as a spot treatment at } \\
3-5 \% \text {. Re-treatments will be required with TIGR to maintain control. }\end{array}$ \\
\hline & Comments: & $\begin{array}{l}\text { A vigorous perennial grass with creeping stolons capable of growing } \\
16 \text { feet long. Stems have hairy nodes and sheaths. Most spread occurs } \\
\text { through vegetative reproduction. }\end{array}$ \\
\hline \multicolumn{3}{|l|}{$\begin{array}{l}\text { POLYGONACEAE (Buckwheat } \\
\text { family) }\end{array}$} \\
\hline \multirow[t]{3}{*}{ Antigonon leptopus } & & Coral vine \\
\hline & Treatment: & Foliar: 5\% glyphosate product, $0.12-0.25 \%$ Milestone, $2-3 \%$ Garlon 4. \\
\hline & Comments: & Widely escaped ornamental. \\
\hline \multicolumn{3}{|l|}{ RHAMNACEAE (Buckthorn family) } \\
\hline \multirow[t]{3}{*}{ Colubrina asiatica } & & Latherleaf \\
\hline & Treatment: & $\begin{array}{l}\text { Manual: hand pull seedlings. Basal bark: } 10-20 \% \text { Garlon } 4 \text { or } 100 \% \\
\text { Pathfinder II. Cut stump: } 50 \% \text { Garlon } 3 \text { A. Foliar: } 3 \% \text { Garlon } 3 \text { A or } 2.25 \% \\
\text { Garlon 4. Follow-up treatments should be done in } 4 \text { weeks. }\end{array}$ \\
\hline & Comments: & $\begin{array}{l}\text { Sprawling shrub commonly invading coastal habitats; has become a } \\
\text { serious pest plant in mangrove and buttonwood habitat and in coastal } \\
\text { hardwood forests. The close proximity to mangroves requires careful } \\
\text { treatment. Capsules spread by tides and currents. Seeds resemble small } \\
\text { pebbles and may be used as crop stones by seed-eating birds, such as } \\
\text { doves, and dispersed. }\end{array}$ \\
\hline \multicolumn{3}{|l|}{ ROSACEAE (Rose family) } \\
\hline \multirow[t]{3}{*}{ Rubus niveus } & & Mysore raspberry \\
\hline & Treatment: & Cut stem: $50 \%$ Garlon 3A or 10\% Garlon 4. \\
\hline & Comments: & $\begin{array}{l}\text { Sharp thorns on stems and leaves; arching stems and branches of intact } \\
\text { plants root where they touch the ground. Seeds are bird- and mammal- } \\
\text { dispersed. }\end{array}$ \\
\hline \multirow[t]{2}{*}{ Eriobotrya japonica } & & Loquat \\
\hline & Treatment: & $\begin{array}{l}\text { Basal bark: } 10 \% \text { Garlon } 4 . \text { Cut stump: } 50 \% \text { Garlon } 3 \text { A or } 10 \% \text { Garlon } 4 . \\
\text { Foliar: } 2 \% \text { Garlon } 3 \text { A or } 1.5 \% \text { Garlon } 4 .\end{array}$ \\
\hline
\end{tabular}




\begin{tabular}{|c|c|c|}
\hline & Comments: & $\begin{array}{l}\text { Invasive in hammocks; commonly cultivated for its yellow, fuzzy, edible } \\
\text { fruit; seeds spread into natural areas by mammals; introduced parrots are } \\
\text { known to feed on the fruit as well, and may also be vectors of seeds. }\end{array}$ \\
\hline \multicolumn{3}{|l|}{ RUBIACEAE (Coffee family) } \\
\hline \multirow[t]{3}{*}{ Paederia cruddasiana } & & Sewer vine \\
\hline & Treatment: & $\begin{array}{l}\text { Foliar: } 0.15-0.25 \% \text { Milestone, } 3-5 \% \text { glyphosate product. Basal bark: } 10 \% \\
\text { Garlon } 4 \text {. Within } 2-4 \text { weeks, re-treat the area with basal applications of } 10 \% \\
\text { Garlon 4. This second treatment can be time-consuming because many } \\
\text { underground runners sprout. The area should continue to be monitored } \\
\text { for follow-up treatments. }\end{array}$ \\
\hline & Comments: & $\begin{array}{l}\text { Climbing vine; related to Paederia foetida, which is established in central } \\
\text { Florida; flowers profusely; produces viable seeds. }\end{array}$ \\
\hline \multirow[t]{3}{*}{ Paederia foetida } & & Skunkvine, Chinese fever vine \\
\hline & Treatment: & $\begin{array}{l}\text { Foliar: } 0.15-0.25 \% \text { Milestone, } 1-3 \% \text { Garlon } 3 \mathrm{~A}, 2 \% \text { Garlon } 4 \text {, or } 1-1.5 \% \\
\text { Plateau. Thoroughly wet foliage. Homeowners can use Brush-B-Gon or } \\
\text { Brush Killer at maximum label rates. Cut stump: } 10 \% \text { Garlon } 4 .\end{array}$ \\
\hline & Comments: & $\begin{array}{l}\text { Perennial twining vine from woody rootstock. Leaves and stems have } \\
\text { disagreeable odor, especially when crushed. Most common in west central } \\
\text { Florida, documented northward to Nassau and Escambia Counties and } \\
\text { southward to Miami-Dade County. }\end{array}$ \\
\hline \multicolumn{3}{|c|}{ RUSCACEAE (Butcher's Broom family) } \\
\hline \multirow[t]{3}{*}{ Sansevieria hyacinthoides } & & Bowstring hemp \\
\hline & Treatment: & $\begin{array}{l}\text { Cut surface (i.e., cut stump): } 10 \% \text { Garlon } 4 \text {. Basal stem (i.e., basal bark): } 10 \% \\
\text { Garlon } 4 \text {. Addition of } 3 \% \text { Stalker may increase consistency where nontarget } \\
\text { vegetation will not be endangered. }\end{array}$ \\
\hline & Comments: & $\begin{array}{l}\text { Plants often take six to twelve months to die. Follow-up applications are } \\
\text { necessary. Dense populations may require initial manual removal. }\end{array}$ \\
\hline \multicolumn{3}{|l|}{ RUTACEAE (Citrus family) } \\
\hline \multirow[t]{3}{*}{ Murraya paniculata } & & Orange jessamine \\
\hline & Treatment: & $\begin{array}{l}\text { Manual: hand pull seedlings. Cut stump: 50\% Garlon 3A. Basal bark: 10\% } \\
\text { Garlon } 4 .\end{array}$ \\
\hline & Comments: & $\begin{array}{l}\text { Shrub or small tree with small, glossy, compound leaves that are fragrant } \\
\text { when crushed; white, citrus-like, heavily perfumed flowers produced in } \\
\text { summertime; small orange fruit are bird-dispersed. Invasive in hammocks, } \\
\text { especially when bordered by residential areas that use this plant in the } \\
\text { landscape. }\end{array}$ \\
\hline \multicolumn{3}{|c|}{ SAPINDACEAE (Soapberry family) } \\
\hline \multirow[t]{3}{*}{ Cupaniopsis anacardioides } & & Carrotwood \\
\hline & Treatment: & $\begin{array}{l}\text { Cut stump: } 10-50 \% \text { Garlon 3A or } 100 \% \text { glyphosate product. Basal bark: } \\
10-20 \% \text { Garlon } 4 \text { or } 100 \% \text { Pathfinder II. Frill or girdle: } 10-20 \% \text { Garlon } 4 \text {. }\end{array}$ \\
\hline & Comments: & $\begin{array}{l}\text { Invades interior of hammocks; bird-dispersed. Note label restrictions with } \\
\text { respect to high-tide mark and use extra caution near mangroves. }\end{array}$ \\
\hline \multirow[t]{3}{*}{ Koelreuteria elegans } & & Golden rain tree, flamegold tree \\
\hline & Treatment: & $\begin{array}{l}\text { Cut stump: } 50 \% \text { glyphosate product or } 50-100 \% \text { Garlon 3A. Basal bark: } \\
25 \% \text { Garlon } 4 \text {. Foliar: } 2-3 \% \text { glyphosate product, } 2 \% \text { Garlon 3A. }\end{array}$ \\
\hline & Comments: & A popular ornamental that has spread from horticultural plantings. \\
\hline \multicolumn{3}{|c|}{ SAPOTACEAE (Sapodilla family) } \\
\hline \multirow[t]{3}{*}{ Manilkara zapota } & & Sapodilla \\
\hline & Treatment: & $\begin{array}{l}\text { Hand pull seedlings. Cut stump: } 50 \% \text { Garlon } 3 \mathrm{~A} \text {. Basal bark: } 10-20 \% \text { Garlon } \\
\text { 4. Larger trees may require repeat applications. }\end{array}$ \\
\hline & Comments: & $\begin{array}{l}\text { Large, spreading tree; edible fruit; seeds dispersed by raccoons and } \\
\text { opossums; invades hammock interiors. }\end{array}$ \\
\hline Pouteria campechiana & & Egg fruit; canistel \\
\hline
\end{tabular}




\begin{tabular}{|c|c|c|}
\hline & Treatment: & Hand pull seedlings. Basal bark: 10\% Garlon 4. \\
\hline & Comments: & $\begin{array}{l}\text { Small to medium tree; yellow, edible fruit; prolific invader of hammocks but } \\
\text { local in distribution; fruit eaten by raccoons and opossums. }\end{array}$ \\
\hline \multicolumn{3}{|c|}{ SOLANACEAE (Nightshade family) } \\
\hline \multirow[t]{3}{*}{ Cestrum diurnum } & & Day jessamine \\
\hline & Treatment: & $\begin{array}{l}\text { Manual: hand pull when possible (if soil disturbance is not an issue). Cut } \\
\text { stump: } 50 \% \text { Garlon } 3 \mathrm{~A} \text {. Basal bark: } 10 \% \text { Garlon } 4 \text {. }\end{array}$ \\
\hline & Comments: & $\begin{array}{l}\text { Shrub or small tree with small, tubular, very fragrant flowers (in daytime). } \\
\text { Small purple fruit dispersed by birds. Fruits are poisonous to humans. }\end{array}$ \\
\hline \multirow[t]{3}{*}{ Solanum diphyllum } & & Twoleaf nightshade \\
\hline & Treatment: & $\begin{array}{l}\text { Hand pull and destroy individual plants when practical. Foliar: } 0.15-0.25 \% \\
\text { Milestone, } 1 \% \text { Garlon } 4,3 \% \text { glyphosate product. }\end{array}$ \\
\hline & Comments: & $\begin{array}{l}\text { Grown in the } 1960 \text { s as an ornamental plant. Fruits are bird-dispersed and } \\
\text { have been spread across south and central Florida. }\end{array}$ \\
\hline \multirow[t]{3}{*}{ Solanum tampicense } & & Wetland nightshade (misleadingly called aquatic soda apple) \\
\hline & Treatment: & $\begin{array}{l}\text { Foliar: } 1.5 \% \text { Garlon } 3 \mathrm{~A}, 0.25 \% \text { Milestone (can be used in seasonally dry } \\
\text { wetlands). Follow-up treatments are necessary. }\end{array}$ \\
\hline & Comments: & $\begin{array}{l}\text { An aggressive invader of wetlands and floodplains. Should be eliminated } \\
\text { whenever located. }\end{array}$ \\
\hline \multirow[t]{3}{*}{ Solanum viarum } & & Tropical soda apple \\
\hline & Treatment: & $\begin{array}{l}\text { Hand pull and destroy individual plants when practical. Foliar: } 0.15-0.25 \% \\
\text { Milestone, } 1 \% \text { Garlon 4, 3\% glyphosate product, or } 0.5 \% \text { Arsenal. }\end{array}$ \\
\hline & Comments: & $\begin{array}{l}\text { Destroy fruit and treat plants immediately after detection. Spreads rapidly. } \\
\text { Livestock and wild animals eat fruits and readily disperse seed. }\end{array}$ \\
\hline \multicolumn{3}{|c|}{ VERBENACEAE (Verbena family) } \\
\hline \multirow{3}{*}{$\begin{array}{l}\text { Lantana camara (Lantana } \\
\text { strigocamara) }\end{array}$} & & Shrub verbena; lantana \\
\hline & Treatment: & $\begin{array}{l}\text { Cut stump: } 50 \% \text { Garlon } 3 \text { A or } 10 \% \text { Garlon } 4 \text {. Basal bark: } 10 \% \text { Garlon } 4 . \\
\text { Foliar: } 0.25 \% \text { Method, } 0.45 \% \text { Vista XRT. Vista XRT is most effective with } \\
\text { repeated fall and spring treatments. }\end{array}$ \\
\hline & Comments: & $\begin{array}{l}\text { Shrub with prickly stems and branches; multicolored flower heads; } \\
\text { ripe fruit is blue. This exotic species should be controlled to help avoid } \\
\text { hybridization with the endemic Lantana depressa. Typically a plant of } \\
\text { roadsides and other disturbed sites, but also invades pineland as well as } \\
\text { hammock margins. Numerous cultivars exist in the nursery trade. }\end{array}$ \\
\hline
\end{tabular}


Table 6. Appendix A: Plants sorted by common name.

\begin{tabular}{|c|c|c|}
\hline Common Name & Scientific Name & Botanical Family Name \\
\hline Air potato & Dioscorea bulbifera & Dioscoreaceae \\
\hline Anil de pasto & Indigofera suffruticosa & Fabaceae \\
\hline Anil indigo & Indigofera suffruticosa & Fabaceae \\
\hline Arjun tree & Terminalia arjuna & Combretaceae \\
\hline Arrowhead vine & Syngonium podophyllum & Araceae \\
\hline Australian pine & Casuarina equisetifolia & Casuarinaceae \\
\hline Bamboo palm & Chamaedorea seifrizii & Arecaceae \\
\hline Bamboo piper & Piper aduncum & Piperaceae \\
\hline Banyan fig & Ficus benghalensis & Moraceae \\
\hline Baquina & Piper umbellatum & Piperaceae \\
\hline Beach naupaka & Scaevola tacadda var. sericea & Goodeniaceae \\
\hline Beach vitex & Vitex rotundifolia & Lamiaceae \\
\hline Beefwood & Casuarina glauca & Casuarinaceae \\
\hline Bishopwood & Bischofia javanica & Euphorbiaceae \\
\hline Black sapote & Diospyros digyna & Ebenaceae \\
\hline Bowstring hemp & Sansevieria hyacinthoides & Ruscaceae \\
\hline Brazilian jasmine & Jasminum fluminense & Oleaceae \\
\hline Brazilian pepper & Schinus terebinthifolia & Anacardiaceae \\
\hline Burma reed & Neyraudia reynaudiana & Poaceae \\
\hline Cadillo & Urena lobata & Malvaceae \\
\hline Caesar weed & Urena lobata & Malvaceae \\
\hline Camphor tree & Cinnamomum camphora & Lauraceae \\
\hline Canistel & Pouteria campechiana & Sapotaceae \\
\hline Carrotwood & Cupaniopsis anacardioides & Sapindaceae \\
\hline Castor bean & Ricinus communis & Euphorbiaceae \\
\hline Cat's-claw vine & Dolichandra unguis-cati & Bignoniaceae \\
\hline Catclaw mimosa & Mimosa pigra & Fabaceae \\
\hline Chinaberry & Melia azedarach & Meliaceae \\
\hline Chinese fan palm & Livistona chinensis & Arecaceae \\
\hline Chinese fever vine & Paederia foetida & Rubiaceae \\
\hline Chinese privet & Ligustrum sinense & Oleaceae \\
\hline Chinese tallow & Triadica sebifera & Euphorbiaceae \\
\hline Chinese wisteria & Wisteria sinensis & Fabaceae \\
\hline Cogongrass & Imperata cylindrica & Poaceae \\
\hline Common guava & Psidium guajava & Myrtaceae \\
\hline Coral ardisia & Ardisia crenata & Myrsinaceae \\
\hline Coral vine & Antigonon leptopus & Polygonaceae \\
\hline Cow itch & Mucuna pruriens & Fabaceae \\
\hline Day jessamine & Cestrum diurnum & Solanaceae \\
\hline Devil tree & Alstonia macrophylla & Apocynaceae \\
\hline Downy rose myrtle & Rhodomyrtus tomentosa & Myrtaceae \\
\hline Earleaf acacia & Acacia auriculiformis & Fabaceae \\
\hline Egg fruit & Pouteria campechiana & Sapotaceae \\
\hline Elliptic yellowwood & Ochrosia elliptica & Apocynaceae \\
\hline False matico & Piper aduncum & Piperaceae \\
\hline
\end{tabular}




\begin{tabular}{|c|c|c|}
\hline Common Name & Scientific Name & Botanical Family Name \\
\hline Fishtail palm (multi-stemmed) & Caryota mitis & Arecaceae \\
\hline Fishtail palm (solitary-trunked) & Caryota urens & Arecaceae \\
\hline Flamegold tree & Koelreuteria elegans & Sapindaceae \\
\hline Giant smutgrass & Sporobolus jacquemontii & Poaceae \\
\hline Glossy privet & Ligustrum lucidum & Oleaceae \\
\hline Gold Coast jasmine & Jasminum dichotomum & Oleaceae \\
\hline Golden bamboo & Phyllostachys aurea & Poaceae \\
\hline Golden pothos & Epipremnum pinnatum cv. aureum & Araceae \\
\hline Golden rain tree & Koelreuteria elegans & Sapindaceae \\
\hline Half flower & Scaevola taccada var. sericea & Goodeniaceae \\
\hline Heavenly bamboo & Nandina domestica & Berberidaceae \\
\hline Indian almond & Terminalia catappa & Combretaceae \\
\hline Indian rosewood & Dalbergia sissoo & Fabaceae \\
\hline Jambolan plum & Syzygium cumini & Myrtaceae \\
\hline Japanese climbing fern & Lygodium japonicum & Lygodiaceae \\
\hline Japanese honeysuckle & Lonicera japonica & Caprifoliaceae \\
\hline Java plum & Syzygium cumini & Myrtaceae \\
\hline Jumbie bean & Leucaena leucocephala & Fabaceae \\
\hline Kudzu & Pueraria montana var. lobata & Fabaceae \\
\hline Lantana & Lantana camara & Verbenaceae \\
\hline Latherleaf & Colubrina asiatica & Rhamnaceae \\
\hline Laurel fig & Ficus microcarpa & Moraceae \\
\hline Lead tree & Leucaena leucocephala & Fabaceae \\
\hline Life plant & Kalanchoe pinnata & Crassulaceae \\
\hline Lofty fig & Ficus altissima & Moraceae \\
\hline Loquat & Eriobotrya japonica & Rosaceae \\
\hline Mahoe & Talipariti tiliaceum var. tiliaceum & Malvaceae \\
\hline Makulan & Piper auritum & Piperaceae \\
\hline Mast wood & Calophyllum antillanum & Clusiaceae \\
\hline Melaleuca & Melaleuca quinquenervia & Myrtaceae \\
\hline Mexican fan palm & Washingtonia robusta & Arecaceae \\
\hline Mexican petunia & Ruellia simplex & Acanthaceae \\
\hline Mimosa & Albizia julibrissin & Fabaceae \\
\hline Mother-of-millions & Kalanchoe x houghtonii & Crassulaceae \\
\hline Australian almond & Terminalia muelleri & Combretaceae \\
\hline Mysore raspberry & Rubus niveus & Rosaceae \\
\hline Napier grass & Pennisetum purpureum & Poaceae \\
\hline Natal grass & Melinis repens & Poaceae \\
\hline Night-blooming cereus & Hylocereus undatus & Cactaceae \\
\hline Ochrosia & Ochrosia elliptica & Apocynaceae \\
\hline Old World climbing fern & Lygodium microphyllum & Lygodiaceae \\
\hline Orange jessamine & Murraya paniculata & Rutaceae \\
\hline Orchid tree & Bauhinia variegata & Fabaceae \\
\hline Oyster plant & Tradescantia spathacea & Commelinaceae \\
\hline Paper mulberry & Broussonetia papyrifera & Moraceae \\
\hline
\end{tabular}




\begin{tabular}{|c|c|c|}
\hline Common Name & Scientific Name & Botanical Family Name \\
\hline Para grass & Urochloa mutica & Poaceae \\
\hline Passionflower & Passiflora edulis & Passifloraceae \\
\hline Peruvian water primrose & Ludwigia peruviana & Onagraceae \\
\hline Popcorn tree & Triadica sebifera & Euphorbiaceae \\
\hline Portia tree & Thespesia populnea & Malvaceae \\
\hline Pride of India & Melia azedarach & Meliaceae \\
\hline Punk tree & Melaleuca quinquenervia & Myrtaceae \\
\hline Purple orchid tree & Bauhinia purpurea & Fabaceae \\
\hline Queen palm & Syagrus romanzoffianum & Arecaceae \\
\hline Queensland umbrella tree & Schefflera actinophylla & Araliaceae \\
\hline Red sandalwood & Adenanthera pavonina & Fabaceae \\
\hline Rosary pea & Abrus precatorius & Fabaceae \\
\hline Rose apple & Syzygium jambos & Myrtaceae \\
\hline Rose Natal grass & Melinis repens & Poaceae \\
\hline Royal poinciana & Delonix regia & Fabaceae \\
\hline Santa Maria & Calophyllum antillanum & Clusiaceae \\
\hline Sapodilla & Manilkara zapota & Sapotaceae \\
\hline Scholar tree & Alstonia scholaris & Apocynaceae \\
\hline Sea hibiscus & Talipariti tiliaceum var. tiliaceum & Malvaceae \\
\hline Seaside mahoe & Thespesia populnea & Malvaceae \\
\hline Senegal date palm & Phoenix reclinata & Arecaceae \\
\hline Sewer vine & Paederia cruddasiana & Rubiaceae \\
\hline Shoebutton ardisia & Ardisia elliptica & Myrsinaceae \\
\hline Shrub verbena & Lantana camara & Verbenaceae \\
\hline Silk reed & Neyraudia reynaudiana & Poaceae \\
\hline Silverthorn & Elaeagnus pungens & Elaeagnaceae \\
\hline Skunkvine & Paederia foetida & Rubiaceae \\
\hline Small-leaf spiderwort & Tradescantia fluminensis & Commelinaceae \\
\hline Solitaire palm & Ptychosperma elegans & Arecaceae \\
\hline Spiked pepper & Piper aduncum & Piperaceae \\
\hline Strawberry guava & Psidium cattleianum & Myrtaceae \\
\hline Suckering Australian pine & Casuarina glauca & Casuarinaceae \\
\hline Surinam cherry & Eugenia uniflora & Myrtaceae \\
\hline Toog & Bischofia javanica & Euphorbiaceae \\
\hline Torpedograss & Panicum repens & Poaceae \\
\hline Tropical soda apple & Solanum viarum & Solanaceae \\
\hline Tung tree & Aleurites fordii & Euphorbiaceae \\
\hline Twoleaf nightshade & Solanum diphyllum & Solanaceae \\
\hline Umbrella tree & Schefflera actinophylla & Araliaceae \\
\hline Velvet bean & Mucuna pruriens & Fabaceae \\
\hline Vera Cruz pepper & Piper auritum & Piperaceae \\
\hline Washingtonia palm & Washingtonia robusta & Arecaceae \\
\hline Wedelia & Sphagneticola trilobata & Asteraceae \\
\hline West Indian dropseed & Sporobolus jacquemontii & Poaceae \\
\hline West Indian indigo & Indigofera suffruticosa & Fabaceae \\
\hline
\end{tabular}




\begin{tabular}{|l|l|l|}
\hline Common Name & Scientific Name & Botanical Family Name \\
\hline West Indian marsh grass & Hymenachne amplexicaulis & Poaceae \\
\hline Wetland nightshade & Solanum tampicense & Solanaceae \\
\hline White cheesewood & Alstonia scholaris & Apocynaceae \\
\hline White orchid tree & Bauhinia aculeata & Fabaceae \\
\hline Wild indigo & Indigofera suffruticosa & Fabaceae \\
\hline Wild taro & Colocasia esculenta & Araceae \\
\hline Winged yam & Dioscorea alata & Dioscoreaceae \\
\hline Woman's tongue & Albizia lebbeck & Fabaceae \\
\hline Wood rose & Merremia tuberosa & Convolvulaceae \\
\hline Zanzibar yam & Dioscorea sansibarensis & Dioscoreaceae \\
\hline
\end{tabular}


Table 7. Appendix B: Plants sorted by scientific name (from Wunderlin et al. 2018).

\begin{tabular}{|c|c|c|}
\hline Scientific Name & Common Name & Botanical Family Name \\
\hline Abrus precatorius & Rosary pea & Fabaceae \\
\hline Acacia auriculiformis & Earleaf acacia & Fabaceae \\
\hline Adenanthera pavonina & Red sandalwood & Fabaceae \\
\hline Albizia julibrissin & Mimosa & Fabaceae \\
\hline Albizia lebbeck & Woman's tongue & Fabaceae \\
\hline Aleurites fordii & Tung tree & Euphorbiaceae \\
\hline Alstonia macrophylla & Devil tree & Apocynaceae \\
\hline Alstonia scholaris & Scholar tree & Apocynaceae \\
\hline Alstonia scholaris & White cheesewood & Apocynaceae \\
\hline Antigonon leptopus & Coral vine & Polygonaceae \\
\hline Ardisia crenata & Coral ardisia & Myrsinaceae \\
\hline Ardisia elliptica & Shoebutton ardisia & Myrsinaceae \\
\hline Bauhinia aculeata & White orchid tree & Fabaceae \\
\hline Bauhinia purpurea & Purple orchid tree & Fabaceae \\
\hline Bauhinia variegata & Orchid tree & Fabaceae \\
\hline Bischofia javanica & Bishopwood & Euphorbiaceae \\
\hline Bischofia javanica & Toog & Euphorbiaceae \\
\hline Broussonetia papyrifera & Paper mulberry & Moraceae \\
\hline Calophyllum antillanum & Mast wood & Clusiaceae \\
\hline Calophyllum antillanum & Santa Maria & Clusiaceae \\
\hline Caryota mitis & Fishtail palm (multi-stemmed) & Arecaceae \\
\hline Caryota urens & Fishtail palm (solitary-trunked) & Arecaceae \\
\hline Casuarina equisetifolia & Australian pine & Casuarinaceae \\
\hline Casuarina glauca & Beefwood & Casuarinaceae \\
\hline Casuarina glauca & Suckering Australian pine & Casuarinaceae \\
\hline Cestrum diurnum & Day jessamine & Solanaceae \\
\hline Chamaedorea seifrizii & Bamboo palm & Arecaceae \\
\hline Cinnamomum camphora & Camphor tree & Lauraceae \\
\hline Colocasia esculenta & Wild taro & Araceae \\
\hline Colubrina asiatica & Latherleaf & Rhamnaceae \\
\hline Cupaniopsis anacardioides & Carrotwood & Sapindaceae \\
\hline Dalbergia sissoo & Indian rosewood & Fabaceae \\
\hline Delonix regia & Royal poinciana & Fabaceae \\
\hline Dioscorea alata & Winged yam & Dioscoreaceae \\
\hline Dioscorea bulbifera & Air potato & Dioscoreaceae \\
\hline Dioscorea sansibarensis & Zanzibar yam & Dioscoreaceae \\
\hline Diospyros digyna & Black sapote & Ebenaceae \\
\hline Dolichandra unguis-cati & Cat's-claw vine & Bignoniaceae \\
\hline Elaeagnus pungens & Silverthorn & Elaeagnaceae \\
\hline Epipremnum pinnatum cv. aureum & Golden pothos & Araceae \\
\hline Eriobotrya japonica & Loquat & Rosaceae \\
\hline Eugenia uniflora & Surinam cherry & Myrtaceae \\
\hline Ficus altissima & Lofty fig & Moraceae \\
\hline Ficus benghalensis & Banyan fig & Moraceae \\
\hline Ficus microcarpa & Laurel fig & Moraceae \\
\hline
\end{tabular}




\begin{tabular}{|c|c|c|}
\hline Scientific Name & Common Name & Botanical Family Name \\
\hline Hylocereus undatus & Night-blooming cereus & Cactaceae \\
\hline Hymenachne amplexicaulis & West Indian marsh grass & Poaceae \\
\hline Imperata cylindrica & Cogongrass & Poaceae \\
\hline Indigofera suffruticosa & Anil de pasto & Fabaceae \\
\hline Indigofera suffruticosa & Anil indigo & Fabaceae \\
\hline Indigofera suffruticosa & West Indian indigo & Fabaceae \\
\hline Indigofera suffruticosa & Wild indigo & Fabaceae \\
\hline Jasminum dichotomum & Gold Coast jasmine & Oleaceae \\
\hline Jasminum fluminense & Brazilian jasmine & Oleaceae \\
\hline Kalanchoe pinnata & Life plant & Crassulaceae \\
\hline Kalanchoe x houghtonii & Mother-of-millions & Crassulaceae \\
\hline Koelreuteria elegans & Flamegold tree & Sapindaceae \\
\hline Koelreuteria elegans & Golden rain tree & Sapindaceae \\
\hline Lantana camara & Lantana & Verbenaceae \\
\hline Lantana camara & Shrub verbena & Verbenaceae \\
\hline Leucaena leucocephala & Jumbie bean & Fabaceae \\
\hline Leucaena leucocephala & Lead tree & Fabaceae \\
\hline Ligustrum lucidum & Glossy privet & Oleaceae \\
\hline Ligustrum sinense & Chinese privet & Oleaceae \\
\hline Livistona chinensis & Chinese fan palm & Arecaceae \\
\hline Lonicera japonica & Japanese honeysuckle & Caprifoliaceae \\
\hline Ludwigia peruviana & Peruvian water primrose & Onagraceae \\
\hline Lygodium japonicum & Japanese climbing fern & Lygodiaceae \\
\hline Lygodium microphyllum & Old World climbing fern & Lygodiaceae \\
\hline Manilkara zapota & Sapodilla & Sapotaceae \\
\hline Melaleuca quinquenervia & Melaleuca & Myrtaceae \\
\hline Melaleuca quinquenervia & Punk tree & Myrtaceae \\
\hline Melia azedarach & Chinaberry & Meliaceae \\
\hline Melia azedarach & Pride of India & Meliaceae \\
\hline Melinis repens & Natal grass & Poaceae \\
\hline Melinis repens & Rose Natal grass & Poaceae \\
\hline Merremia tuberosa & Wood rose & Convolvulaceae \\
\hline Mimosa pigra & Catclaw mimosa & Fabaceae \\
\hline Mucuna pruriens & Cow itch & Fabaceae \\
\hline Mucuna pruriens & Velvet bean & Fabaceae \\
\hline Murraya paniculata & Orange jessamine & Rutaceae \\
\hline Nandina domestica & Heavenly bamboo & Berberidaceae \\
\hline Neyraudia reynaudiana & Burma reed & Poaceae \\
\hline Neyraudia reynaudiana & Silk reed & Poaceae \\
\hline Ochrosia elliptica & Elliptic yellowwood & Apocynaceae \\
\hline Ochrosia elliptica & Ochrosia & Apocynaceae \\
\hline Paederia cruddasiana & Sewer vine & Rubiaceae \\
\hline Paederia foetida & Chinese fever vine & Rubiaceae \\
\hline Paederia foetida & Skunkvine & Rubiaceae \\
\hline Panicum repens & Torpedograss & Poaceae \\
\hline
\end{tabular}




\begin{tabular}{|c|c|c|}
\hline Scientific Name & Common Name & Botanical Family Name \\
\hline Passiflora edulis & Passionflower & Passifloraceae \\
\hline Pennisetum purpureum & Napier grass & Poaceae \\
\hline Phoenix reclinata & Senegal date palm & Arecaceae \\
\hline Phyllostachys aurea & Golden bamboo & Poaceae \\
\hline Piper aduncum & Bamboo piper & Piperaceae \\
\hline Piper aduncum & False matico & Piperaceae \\
\hline Piper aduncum & Spiked pepper & Piperaceae \\
\hline Piper auritum & Makulan & Piperaceae \\
\hline Piper auritum & Vera Cruz pepper & Piperaceae \\
\hline Piper umbellatum & Baquina & Piperaceae \\
\hline Pouteria campechiana & Canistel & Sapotaceae \\
\hline Pouteria campechiana & Egg fruit & Sapotaceae \\
\hline Psidium cattleianum & Strawberry guava & Myrtaceae \\
\hline Psidium guajava & Common guava & Myrtaceae \\
\hline Ptychosperma elegans & Solitaire palm & Arecaceae \\
\hline Pueraria montana var. lobata & Kudzu & Fabaceae \\
\hline Rhodomyrtus tomentosa & Downy rose myrtle & Myrtaceae \\
\hline Ricinus communis & Castor bean & Euphorbiaceae \\
\hline Rubus niveus & Mysore raspberry & Rosaceae \\
\hline Ruellia simplex & Mexican petunia & Acanthaceae \\
\hline Sansevieria hyacinthoides & Bowstring hemp & Ruscaceae \\
\hline Scaevola taccada var. sericea & Beach naupaka & Goodeniaceae \\
\hline Scaevola taccada var. sericea & Half flower & Goodeniaceae \\
\hline Schefflera actinophylla & Queensland umbrella tree & Araliaceae \\
\hline Schefflera actinophylla & Umbrella tree & Araliaceae \\
\hline Schinus terebinthifolia & Brazilian pepper & Anacardiaceae \\
\hline Solanum diphyllum & Twoleaf nightshade & Solanaceae \\
\hline Solanum tampicense & Wetland nightshade & Solanaceae \\
\hline Solanum viarum & Tropical soda apple & Solanaceae \\
\hline Sphagneticola trilobata & Wedelia & Asteraceae \\
\hline Sporobolus jacquemontii & Giant smutgrass & Poaceae \\
\hline Sporobolus jacquemontii & West Indian dropseed & Poaceae \\
\hline Syagrus romanzoffianum & Queen palm & Arecaceae \\
\hline Syngonium podophyllum & Arrowhead vine & Araceae \\
\hline Syzygium cumini & Jambolan plum & Myrtaceae \\
\hline Syzygium cumini & Java plum & Myrtaceae \\
\hline Syzygium jambos & Rose apple & Myrtaceae \\
\hline Talipariti tiliaceum var. tiliaceum & Mahoe & Malvaceae \\
\hline Talipariti tiliaceum var. tiliaceum & Sea hibiscus & Malvaceae \\
\hline Terminalia arjuna & Arjun tree & Combretaceae \\
\hline Terminalia catappa & Indian almond & Combretaceae \\
\hline Terminalia muelleri & Australian almond & Combretaceae \\
\hline Thespesia populnea & Portia tree & Malvaceae \\
\hline Thespesia populnea & Seaside mahoe & Malvaceae \\
\hline Tradescantia fluminensis & Small-leaf spiderwort & Commelinaceae \\
\hline
\end{tabular}




\begin{tabular}{|l|l|l|}
\hline \multicolumn{1}{|c|}{ Scientific Name } & \multicolumn{1}{c|}{ Common Name } & Botanical Family Name \\
\hline Tradescantia spathacea & Oyster plant & Commelinaceae \\
\hline Triadica sebifera & Chinese tallow & Euphorbiaceae \\
\hline Triadica sebifera & Popcorn tree & Euphorbiaceae \\
\hline Urena lobata & Cadillo & Malvaceae \\
\hline Urena lobata & Caesar weed & Malvaceae \\
\hline Urochloa mutica & Para grass & Poaceae \\
\hline Vitex rotundifolia & Beach vitex & Lamiaceae \\
\hline Washingtonia robusta & Mexican fan palm & Arecaceae \\
\hline Washingtonia robusta & Washingtonia palm & Arecaceae \\
\hline Wisteria sinensis & Chinese wisteria & Fabaceae \\
\hline
\end{tabular}

